\title{
Glutamatergic Enteric Neurons
}

\author{
Min-Tsai Liu, ${ }^{1}$ Jeffrey D. Rothstein, ${ }^{2}$ Michael D. Gershon, ${ }^{1}$ and Annette L. Kirchgessner ${ }^{1}$ \\ ${ }^{1}$ Department of Anatomy and Cell Biology, Columbia University College of Physicians and Surgeons, New York, New York \\ 10032, and 2Department of Neurology, The Johns Hopkins University, Baltimore, Maryland 21224-6522
}

\begin{abstract}
We tested the hypothesis that glutamate, the major excitatory neurotransmitter of the CNS, is also an excitatory neurotransmitter in the enteric nervous system (ENS). Glutamate immunoreactivity was found in cholinergic enteric neurons, many of which were identified as sensory by their co-storage of substance $\mathrm{P}$ and/or calbindin. Glutamate immunoreactivity was concentrated in terminal varicosities with a majority of small clear synaptic vesicles. The immunoreactivities of both AMPA and NMDA receptor subunits were also detected on neurons in both submucosal and myenteric plexuses. The immunoreactivity of the EAAC1 neuronal glutamate transporter was widespread in both plexuses. Glutamate evoked depolarizing responses in myenteric neurons that had fast and slow
\end{abstract}

components. The fast component was mimicked by AMPA, and the slow component was mimicked by NMDA. The fast component and the response to AMPA mimicked fast EPSPs evoked in 2/AH neurons; moreover, fast EPSPs as well as fast glutamate and AMPA responses were blocked by selective AMPA antagonists and potentiated by the glutamate uptake inhibitor L-(-)-threo-3-hydroxyaspartic acid. These observations demonstrate, for the first time, the presence of glutamatergic neurons and glutamate-mediated neurotransmission in the ENS.

Key words: enteric nervous system; electrophysiology; excitatory amino acids; glutamate transporters; sensory neurons; depolarization
The enteric nervous system (ENS) is the only region of the peripheral nervous system that is intrinsically capable of mediating reflex activity (Furness and Costa, 1987; Gershon et al., 1994). This activity is made possible by the presence within the bowel of microcircuits that contain the necessary primary afferent neurons and interneurons, as well as the excitatory and inhibitory motor neurons that innervate gastrointestinal smooth muscle and glands. The complexity of the functions controlled by the ENS is reflected in an equally complex organization that resembles that of the CNS more than the remainder of the PNS. Many different classes of neurotransmitter have been found in the ENS, including most of those known also to be present in the CNS. Glutamate, the major excitatory neurotransmitter of the brain (Monaghan et al., 1989; Gasic, 1995), has seemed to be a conspicuous exception in that it has not previously been found to be a neurotransmitter in the ENS. mRNA encoding NMDA receptors is present in enteric neurons (Burns et al., 1994; Burns and Stephens, 1995), and pharmacological studies have also been consistent with the idea that neurogenic motile (Wiley et al., 1991) or secretory (Rhoads et al., 1995) responses of the gut involve enteric glutamatergic receptors. "Shellfish poisoning," which is caused by the ingestion of mussels contaminated by domoic acid, a potent ionotropic non-NMDA receptor agonist, is characterized by severe gastrointestinal distress (nausea, vomiting, and

Received Feb. 3, 1997; revised March 26, 1997; accepted March 31, 1997.

This work was supported by National Institutes of Health Grants NS 27645, NS 01582, NS 35951 (A.L.K.), NS 33958 (J.D.R.), and NS 12969 (M.D.G.). We thank Drs. R. Ambron, I. Kupfermann, and A. MacDermott for helpful comments and suggestions and W. Setlik and T. Swayne for excellent technical assistance. We are especially grateful to Dr. R. J. Wenthold (National Institutes of Health) for his generous contribution of antibodies to GluR1-4, NR1, and NR2A/B and helpful discussions.

Correspondence should be addressed to Dr. Annette Kirchgessner, Department of Anatomy and Cell Biology, Columbia University, College of Physicians and Surgeons, 630 West 168th Street, New York, NY 10032.

Copyright (C) 1997 Society for Neuroscience $0270-6474 / 97 / 174764-21 \$ 05.00 / 0$ diarrhea) (Perl et al., 1990). We now report, for the first time, that glutamate mediates excitatory synaptic transmission in enteric neurons, that enteric neurons express the neuronal glutamate transporter, EAAC1, NMDA, and non-NMDA (AMPA) receptors, and that a subset of enteric neurons that previously have been demonstrated to be sensory (Kirchgessner et al., 1992; Bornstein, 1994) are glutamatergic. These findings are consistent with the idea that glutamate is an excitatory enteric neurotransmitter and support the possibility that intrinsic sensory neurons use glutamate as a transmitter.

\section{MATERIALS AND METHODS}

Immunocytochemistry. Male guinea pigs $(\sim 350 \mathrm{gm})$ were stunned by a blow to the head and exsanguinated. This procedure has been approved by the Animal Use and Care Committee of Columbia University. After the abdominal cavity was opened, the gut was rapidly removed and placed in a beaker of Krebs' solution, which was kept on ice. The gut was opened along the mesenteric border, and the resulting rectangular sheet of intestine was pinned flat, mucosal side up. Laminar longitudinal musclemyenteric plexus (LMMP) preparations or the dissected submucosa (containing the submucosal plexus) were fixed for $3 \mathrm{hr}$ with $4 \%$ formaldehyde (freshly prepared from paraformaldehyde) in $0.1 \mathrm{M}$ sodium phosphate buffer, $\mathrm{pH} 7.4$, at room temperature and washed three times with PBS. The methods used to obtain whole mounts were similar to those described previously (Kirchgessner and Gershon, 1988). To locate receptor or transporter proteins in the tissue by immunocytochemistry, freefloating preparations were exposed to PBS containing $0.5-1.0 \%$ Triton $\mathrm{X}-100$ and $4 \%$ horse serum for $30 \mathrm{~min}$ to permeabilize the tissue and to reduce background staining. Immunoreactivity was then demonstrated by incubating the tissues with affinity-purified rabbit polyclonal antibodies $\left(48 \mathrm{hr}, 4^{\circ} \mathrm{C}\right)$ to glutamate receptor subunits or the neuronal glutamate transporter EAAC1. The sources of these antibodies and the evidence of their specificity are cited in Table 1 . As part of their characterization, immunostaining by all primary antibodies used in this studied was abolished by preabsorption with the synthetic peptide used for immunization. Antibodies against glutamate receptor subunits GluR1, 2/3, and 4, and NR1 and NR2A/B have been well characterized in both brain (Petralia and Wenthold, 1992; Wenthold et al., 1992; Petralia et al., 1994a,b) and 


\begin{tabular}{|c|c|c|c|c|}
\hline Antiserum & $\begin{array}{l}\text { Host } \\
\text { species }\end{array}$ & Dilution & Source & Demonstration of specificity, citations \\
\hline Glutamate & Rabbit & $1: 500$ & $\begin{array}{l}\text { Chemicon International Inc. } \\
\text { (Temecula, CA) }\end{array}$ & Marc et al., 1990; Kalloniatis and Fletcher, 1993 \\
\hline GluR1 & Rabbit & $1.0 \mu \mathrm{g} / \mathrm{ml}$ & Gift of Dr. R. J. Wenthold, NIH ${ }^{a}$ & Petralia and Wenthold, 1992; Wenthold et al., 1992 \\
\hline GluR2/3 & Rabbit & $0.5 \mu \mathrm{g} / \mathrm{ml}$ & Gift of Dr. R. J. Wenthold, NIH & $\begin{array}{l}\text { Petralia and Wenthold, 1992; Wenthold et al., 1992; } \\
\text { recognizes both subunit proteins }\end{array}$ \\
\hline GluR4 & Rabbit & $1.0 \mu \mathrm{g} / \mathrm{ml}$ & Gift of Dr. R. J. Wenthold, NIH & Petralia and Wenthold, 1992; Wenthold et al., 1992 \\
\hline NR1 & Rabbit & $1.0 \mu \mathrm{g} / \mathrm{ml}$ & Gift of Dr. R. J. Wenthold, NIH & $\begin{array}{l}\text { Petralia et al., 1994b; directed against the } C \text { terminus of } \\
\text { the rat NMDAR } 1 \text { receptor and recognizes } 4 \text { of the } 8 \\
\text { receptor splice variants }\end{array}$ \\
\hline $\mathrm{NR} 2 \mathrm{~A} / \mathrm{B}$ & Rabbit & $1.0 \mu \mathrm{g} / \mathrm{ml}$ & Gift of Dr. R. J. Wenthold, NIH & $\begin{array}{l}\text { Petralia et al., } 1994 \mathrm{a} \text {; recognizes the A and B subunits of } \\
\text { the NMDAR2 receptor }\end{array}$ \\
\hline EAAC1 & Rabbit & $0.06 \mu \mathrm{g} / \mathrm{ml}$ & Laboratory of J. Rothstein & Rothstein et al., 1993 \\
\hline Substance P & Rat & $1: 1000$ & Accurate Chemical Co. (Westbury, NY) & $\begin{array}{l}\text { Cuello et al., 1979; Mawe and Gershon 1989; this antibody } \\
\text { is directed against the 5-8 C-terminal fragment and thus } \\
\text { will not react with substance K (neuromedin A) }\end{array}$ \\
\hline ChAT & Goat & $1: 300$ & Chemicon International Inc. & Neunlist and Schemann, 1997 \\
\hline $\begin{array}{l}\text { Nitric oxide } \\
\text { synthase }\end{array}$ & Mouse & $1: 1000$ & Transduction Labs (Lexington, KY) & $\begin{array}{l}\text { This antibody is directed against amino acids } 1095-1289 \\
\text { of human brain (NOS) }\end{array}$ \\
\hline Calretinin & Goat & $1: 6000$ & Chemicon International Inc. & Jacobowitz and Winsky, 1991 \\
\hline Calbindin & Mouse & $1: 100$ & Sigma & Reacts specifically with calbindin-D (28 kDa) \\
\hline $\begin{array}{l}\text { Vasoactive } \\
\text { intestinal } \\
\text { polypeptide }\end{array}$ & Mouse & $1: 500$ & $\begin{array}{l}\text { CURE/Gastroenteric Biology Center, } \\
\text { antibody/RIA core, NIH Grant } \\
\text { DK41301 }\end{array}$ & McConalogue et al., 1995; Wong et al., 1996 \\
\hline
\end{tabular}

${ }^{a} \mathrm{NIH}$, National Institutes of Health.

periphery (Weaver et al., 1996). These antibodies were raised against synthetic peptides corresponding to C-terminal sequences for each of the respective rat subunits. The $\mathrm{C}$-terminal sequences of the GluR2 and GluR3 glutamate receptor subunits show nearly identical sequence homology; therefore, this antibody identifies both subunit proteins. Antisera generated against the $\mathrm{C}$ terminus peptide of rat NR2A (Petralia et al., 1994b) recognize both NR2A and NR2B subunits equally well; however, no cross-reaction is seen with NR1 or other glutamate receptor subunits. Antibodies against the neuronal glutamate transporter EAAC1 recognize the $\mathrm{C}$ terminus domain of the transporter (Rothstein et al., 1994). Bound antibodies were visualized by incubating tissues for $3 \mathrm{hr}$ with indocarbocyanine (Cy3)- or fluorescein isothiocyanate (FITC)-labeled secondary antibodies to rabbit IgG (Jackson ImmunoResearch, West Grove, PA) diluted 1:4000 (Cy3) or 1:200 (FITC). After washing with PBS, the tissues were coverslipped with Vectashield (Vector Laboratories, Burlingame, CA). In every experiment, parallel control sections were included that were incubated with normal rabbit serum instead of primary antibodies. Cy3 fluorescence was visualized by vertical fluorescence microscopy using a Chroma optical filter set (excitation, $540 \pm 12.5 \mathrm{~nm}$; dichroic, $565 \mathrm{~nm}$; emission, $605 \pm 27.5 \mathrm{~nm}$ ). FITC fluorescence was viewed with a Chroma optical filter set (excitation, $480 \pm 15 \mathrm{~nm}$; dichroic, $505 \mathrm{~nm}$; emission, $535 \pm 20 \mathrm{~nm}$ ). Double label immunocytochemistry was used to identify the cells that express AMPA receptor subunits and the EAAC1 transporter. Double labeling was made possible by using primary antibodies raised in different species (Table 1) in conjunction with species-specific secondary antibodies [goat anti-rat and goat anti-mouse (Kirkegaard and Perry, Gaithersburg, MD) or donkey anti-goat (Jackson ImmunoResearch); diluted 1:200] coupled to contrasting fluorophores (FITC or $\mathrm{Cy} 3)$.

Glutamate-immunoreactive structures in the guinea pig and rat bowel were identified by immunocytochemistry with rabbit antibodies to glutamate (Table 1). Tissues were fixed with paraformaldehyde $(4.0 \%)$ and glutaraldehyde $(0.1 \%)$ for $1 \mathrm{hr}$ (at room temperature). These antibodies are specific for glutamate fixed to proteins by glutaraldehyde. Preparations were then placed in sodium cyanoborohydride (1.0\% for $30 \mathrm{~min})$, rinsed, and processed by immunocytochemistry, as described above. The primary antibody (diluted 1:500-1000) was applied for $24-48 \mathrm{hr}\left(\right.$ at $\left.4^{\circ} \mathrm{C}\right)$. In some cases, preparations were incubated with horseradish peroxidase- labeled secondary antibodies to rabbit IgG (diluted 1:100; Vector Laboratories). Immunostaining was visualized with diaminobenzidine tetrahydrochloride and examined on a Zeiss Axiovert microscope.

Postembedding staining with colloidal gold was carried out as described by van den Pol (1991). Laminar preparations of guinea pig small intestine were fixed for $1 \mathrm{hr}$ with $3.0 \%$ glutaraldehyde in $0.1 \mathrm{M}$ sodium phosphate buffer ( $\mathrm{pH}$ 7.4) at room temperature. LMMPs were treated with $1.0 \%$ osmium tetroxide $(1 \mathrm{hr})$ and embedded in Epon 812. Ultrathin sections were cut on a Reichert microtome and picked up on Formvarcoated grids. Sections were then etched with saturated sodium metaperiodate $(30 \mathrm{~min})$, washed in distilled $\mathrm{H}_{2} \mathrm{O}$, and incubated $(30 \mathrm{~min})$ with sodium cyanoborohydride $(1 \%)$ to quench reactive aldehydes. Sections were incubated with the primary antiserum (diluted 1:100; 4 days at $4^{\circ} \mathrm{C}$ ), followed by several washes, and then with $10 \mathrm{~nm}$ particles of colloidal gold (1:20) adsorbed to goat anti-rabbit IgG (BB International, Cardiff, England; $2 \mathrm{hr})$. The grids were washed, stained with uranyl acetate (10 $\mathrm{min})$ and lead citrate (20 min), and examined in a JEOLCO 1200 EX electron microscope. Control sections were incubated without primary antibody.

Confocal microscopy. Whole mounts were examined using an LSM 410 laser scanning confocal microscope (Zeiss, Thornwood, NY) equipped with a krypton/argon laser and attached to a Zeiss Axiovert $100 \mathrm{TV}$ microscope. Usually, 20-30 optical sections were taken at $0.5 \mu \mathrm{m}$ intervals. Images of $512 \times 512$ pixels were obtained and processed using Adobe Photoshop 3.0 (Adobe Systems, Mountain View, CA) and printed using a Tektronix Phaser 440 printer.

Electrophoresis and immunoblotting. Brains were removed from metofane-anesthetized, decapitated rats. Tissue from gut was removed from stunned and exsanguinated guinea pigs. Twenty micrograms of protein from brain (cortex) and $40 \mu \mathrm{g}$ of protein from LMMP preparations of gut were subjected to SDS-PAGE ( $7.5 \%$ polyacrylamide). The proteins were then blotted onto nitrocellulose membranes $(100 \mathrm{~V}$, $1 \mathrm{hr}$ ), treated with 5\% nonfat dry milk in Tris-buffered saline with $0.05 \%$ Tween 20 , and probed with purified rabbit polyclonal antibodies selective for the GR1 (diluted 1:500), GR2/3 (diluted 1:500), GR4 (diluted 1:500), NR1 (diluted 1:500), and NR2A/B (diluted 1:500) subunits of the glutamate receptor and the neuronal glutamate transporter EAAC1 (diluted 1:500). Immunoreactive bands were demon- 
Table 2. Coincident expression of glutamate, glutamate receptors, and the neuronal glutamate transporter with other markers in the guinea pig small intestine

\begin{tabular}{|c|c|c|c|c|c|c|c|c|c|c|c|}
\hline \multirow[b]{2}{*}{ Marker } & \multicolumn{6}{|c|}{ Myenteric plexus } & \multicolumn{5}{|c|}{ Submucosal plexus } \\
\hline & $\begin{array}{l}\text { Cells/ } \\
\text { ganglion }\end{array}$ & Substance P & Calbindin & ChAT & Calretinin & NOS & $\begin{array}{l}\text { Cells/ } \\
\text { ganglion }\end{array}$ & Substance P & Calbindin & ChAT & VIP \\
\hline Glutamate & $\begin{array}{c}4.0 \pm 1.5 \\
(n=50)\end{array}$ & $78.3^{a}$ & $8.3^{a}$ & $100.0^{a}$ & 0.0 & ND & $\begin{array}{l}2.1 \pm 0.2 \\
(n=100)\end{array}$ & $100.0^{b}$ & $8.3^{b}$ & $100.0^{a}$ & 0.0 \\
\hline GluR1 & $\begin{array}{r}26.4 \pm 2.9 \\
(n=50)\end{array}$ & $80.5^{b}$ & $57.7^{a}$ & $100^{a}$ & $38.5^{a}$ & $11.5^{a}$ & $\begin{array}{l}4.2 \pm 0.3 \\
(n=150)\end{array}$ & $18.6^{b}$ & $6.7^{b}$ & $100.0^{a}$ & 0.0 \\
\hline GluR2/3 & $\begin{array}{r}32.4 \pm 2.9 \\
(n=50)\end{array}$ & ND & 0.0 & $51.0^{a}$ & $12.2^{b}$ & $48.5^{b}$ & $\begin{array}{l}7.1 \pm 0.8 \\
(n=150)\end{array}$ & $25.0^{b}$ & $<0.5^{b}$ & $58.5^{b}$ & $40.3^{b}$ \\
\hline GluR4 & $\begin{array}{r}27.7 \pm 2.5 \\
\quad(n=50)\end{array}$ & ND & 0.0 & $100.0^{a}$ & $66.7^{b}$ & 0.0 & $\begin{array}{l}5.2 \pm 0.7 \\
\quad(n=150)\end{array}$ & $30.0^{b}$ & $<1.0^{b}$ & $44.7^{a}$ & $62.4^{b}$ \\
\hline EAAC1 & $\begin{aligned} 18.3 & \pm 1.0 \\
(n & =100)\end{aligned}$ & ND & $86.7^{b}$ & $100.0^{a}$ & 0.0 & 0.0 & $\begin{array}{l}2.6 \pm 0.1 \\
(n=150)\end{array}$ & $70.3^{b}$ & $4.1^{b}$ & $100.0^{a}$ & 0.0 \\
\hline
\end{tabular}

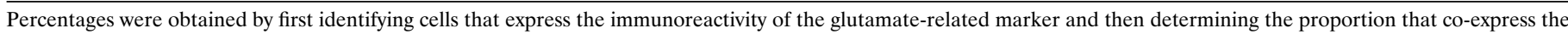

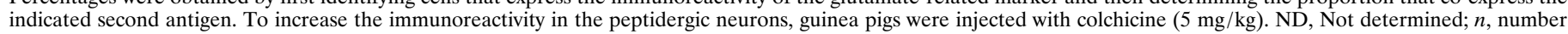
of ganglia examined.

${ }^{a}$ The glutamate-related marker is present in a subset of cells that express the second antigen.

${ }^{b}$ The glutamate-related marker is present in all of the cells that express the second antigen.

strated with goat anti-rabbit secondary antibodies conjugated to horseradish peroxidase (HRP; diluted 1:1000; Bio-Rad, Richmond, CA). HRP activity was visualized with enhanced chemiluminescence (New England Nuclear, Boston, MA). Molecular weights were estimated using biotinylated standards myosin $(200 \mathrm{kDa}), \beta$-galactosidase (116 $\mathrm{kDa})$, phosphorylase B (97 kDa), BSA (66 kDa), and ovalbumin (45 $\mathrm{kDa})$, obtained from Bio-Rad.

Electrophysiology. Male guinea pigs (250-350 gm) were stunned and exsanguinated. A segment of the ileum was excised and placed in oxygenated $\left(95 \% \mathrm{O}_{2}\right.$ and $\left.5 \% \mathrm{CO}_{2}\right)$ Krebs' solution of the following composition (mM): $\mathrm{NaCl}$ (121.3), $\mathrm{KCl}$ (5.95), $\mathrm{CaCl}_{2}$ (2.5), $\mathrm{NaHCO}_{3}$ (14.3), $\mathrm{NaH}_{2} \mathrm{PO}_{4}$ (1.34), $\mathrm{MgCl}_{2}$ (1.2), and glucose (12.7). The Krebs' solution contained nifedipine $(1.0 \mu \mathrm{M})$ and scopolamine $(1.0 \mu \mathrm{M})$ to block longitudinal muscle contractions while intracellular recordings were obtained. A $5.0 \mathrm{~mm}^{2}$ segment of the ileum was cut open and pinned (mucosal surface up) in a dish coated with a silicone elastomer. Preparations of LMMP were dissected, transferred to a recording chamber (volume, 1.0 $\mathrm{ml}$ ), and stretched lightly with stainless steel pins. Preparations were superfused $\left(3.0 \mathrm{ml} / \mathrm{min}, 36^{\circ} \mathrm{C}\right)$ with oxygentated Krebs' solution. Myenteric ganglia were visualized on the stage of a Zeiss Axiovert inverted microscope at a magnification of $10 \times$. Intracellular recordings were obtained from neurons using glass microelectrodes filled with $2.0 \mathrm{M} \mathrm{KCl}$ (tip resistance, $70-200 \mathrm{M} \Omega$ ). A negative capacity compensation amplifier (Axoclamp 2B) was used to record the transmembrane potential difference and to inject current via the recording electrode. Rectangular electrical current pulses with a duration of $40-400 \mathrm{msec}$ were injected through the microelectrode and were driven by Grass S88 stimulators (Grass Instruments, Quincy, MA). Satisfactory impalements resulted in a stable resting membrane potential of $-35 \mathrm{mV}$ or greater. The input resistance of the impaled cell was determined after the injection of a 0.1-0.9 nA hyperpolarizing current pulse (40-100 msec duration). Membrane potentials and intracellular current injections were displayed on a digital storage oscilloscope (DSO450; Gould, Cleveland, $\mathrm{OH}$ ), and permanent records were made on a thermal array chart recorder (TA240, Gould) and recorded on a videotape recorder (model 200; Vetter, Rebersburg, PA). Synaptic inputs were investigated by stimulating interganglionic fiber tracts with a monopolar extracellular electrode made from Teflon-insulated platinum wire ( $25 \mu \mathrm{m}$ diameter). To evoke a fast EPSP, nerve fibers were stimulated using single stimuli of $0.5 \mathrm{msec}$ duration applied at a rate of $0.5 \mathrm{~Hz}$. When studying fast EPSPs, four consecutive responses obtained from the same cell were averaged, first before application of experimental compounds and then again after they were applied. Data are expressed as mean \pm SEM. Inhibition of the EPSP is expressed as the percent change from the predrug amplitude. ANOVA followed by Dunnett's $t$ test (StatView) was used to test for significance $(p<0.05)$.

Compounds were applied to neurons either by ejection with pressure from a micropipette $(\sim 5.0 \mu \mathrm{m}$ diameter) filled with a $20.0 \mathrm{~mm}$ (glutamate) or $10.0 \mathrm{~mm}$ (AMPA, NMDA, and nicotine) solution or by addition to the fluid superfusing the preparations. In superfused preparations, compounds ejected from micropipettes were diluted $\sim 100$-fold (Wade et al., 1994). Compounds used included: (1) from Sigma (St. Louis, MO), tetrodotoxin, hexamethonium, bicuculline, and glycine; (2) from Tocris Cookson (St. Louis, MO), D-2-amino-5-phosphonopentanoate (AP5), L-trans-pyrrolidine-2,4-dicarboxylate (PDC), and L-(-)-threo-3-hydoxyaspartic acid (THA); and (3) from Research Biochemicals International (Natick, MA), AMPA, cyclothiazide, NMDA, nicotine, glutamic acid, 6-cyano-7-nitroquinoxaline-2,3-dione (CNQX), 6,7-dinitroquinoxaline-2, 3-dione (DNQX), suramin, and $( \pm)-3$-(2-carboxypiperazin-4-yl)-propyl1-phosphonic acid (CPP).

Intracellular labeling with Neurobiotin. To visualize the shapes of enteric neurons from which recordings were made, intracellular microelectrodes were filled with $2.0 \%$ Neurobiotin (Vector Laboratories) in $1.0 \mathrm{M} \mathrm{KCl}$. After impaled neurons had been characterized electrophysiologically, a depolarizing current was passed through the microelectrodes $(0.4-0.6$ $\mathrm{nA}, 200 \mathrm{msec}$ for $25 \mathrm{~min}$ ) to inject the Neurobiotin. After dye injection, the preparations were fixed and permeabilized, as described above. Preparations were then incubated with streptavidin (Vector; 1:200) conjugated to FITC for $1 \mathrm{hr}$.

\section{RESULTS}

\section{Glutamate-immunoreactive neurons are present in both enteric plexuses}

If glutamate is an enteric neurotransmitter, then as in other sites where glutamatergic neurons exist, the enteric plexuses would be expected to contain neurons that can be demonstrated with glutamate-selective antibodies (Marc et al., 1990; van den Pol, 1991). Glutamate-immunoreactive neurons were found in ganglia of the myenteric (Fig. $1 A, F$ ) and submucosal (Fig. 1C,E,G) plexuses in both guinea pigs (Fig. $1 A-D, G$ ) and rats (Fig. $1 E, F$, Table 2 ). The frequency of such cells in each plexus was relatively low but was higher in the rat than in the guinea pig. All of the submucosal glutamate-immunoreactive neurons in the guinea pig bowel co-expressed substance $\mathrm{P}$ and choline acetyltransferase (ChAT) immunoreactivities (Fig. $1 G, H$ ) and a subset also contained calbindin immunoreactivity (Table 2). All of the glutamateimmunoreactive neurons of the guinea pig myenteric plexus contained ChAT immunoreactivity, and most also contained 

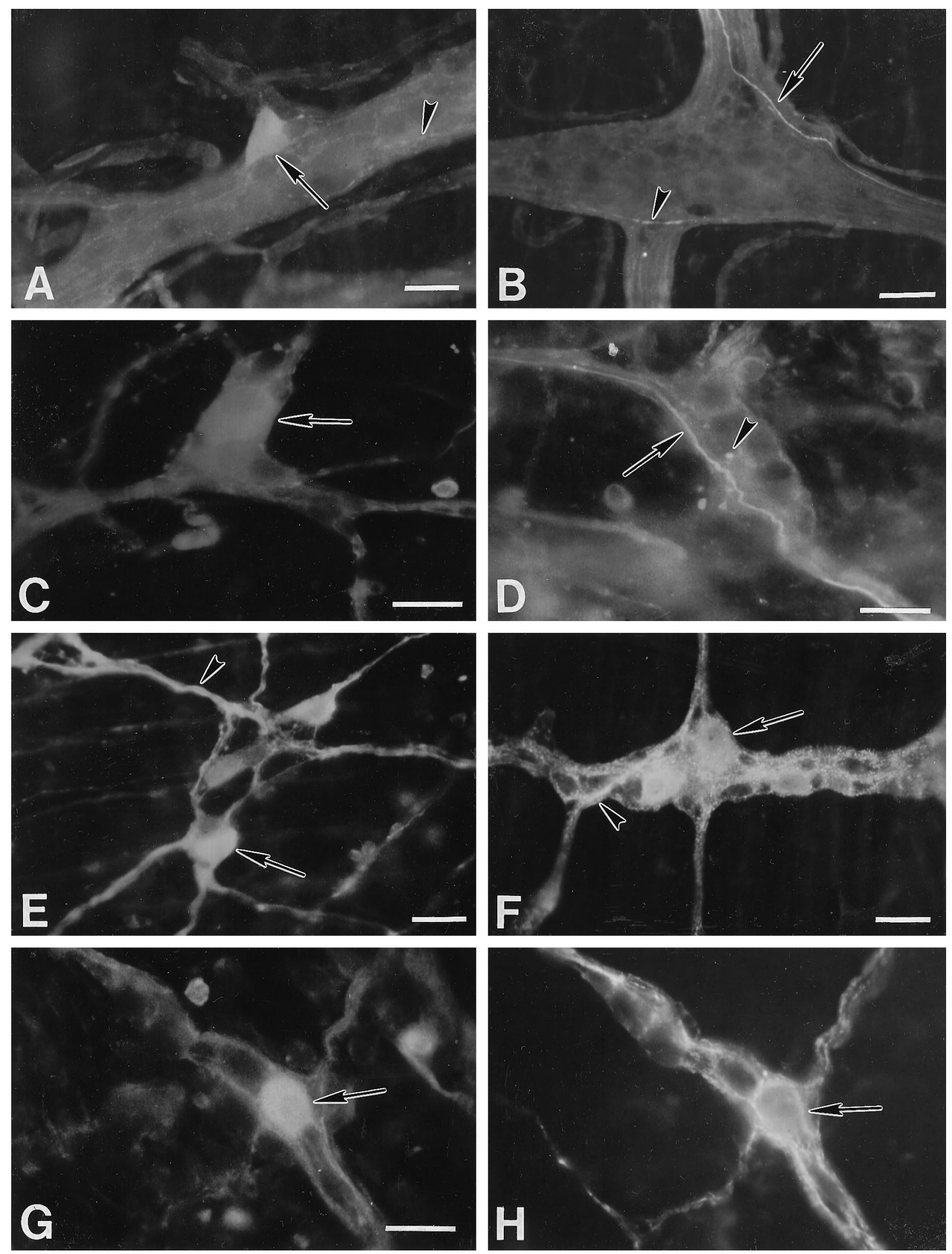

Figure 1. Glutamate immunoreactivity in the guinea pig and rat small intestine. $A-D$, Guinea pig ileum. A subset of neurons in the myenteric $(A)$ and submucosal $(C)$ plexus are glutamate-immunoreactive (arrow). Varicose (arrowhead) and smooth (arrow) glutamate-immunoreactive nerve fibers are found in myenteric $(B)$ and submucosal $(D)$ ganglia. Glutaraldehyde-induced background autofluorescence is present. $E$, $F$, Rat ileum. Glutamateimmunoreactive neurons (arrow) and nerve fibers (arrowhead) are numerous in submucosal $(E)$ and myenteric $(F)$ ganglia. $G, H$, Guinea pig ileum. Glutamate immunoreactivity $(G)$ is expressed by all substance P-immunoreactive neurons $(H)$ in the submucosal plexus (arrow). Scale bar, $30 \mu \mathrm{m}$. 


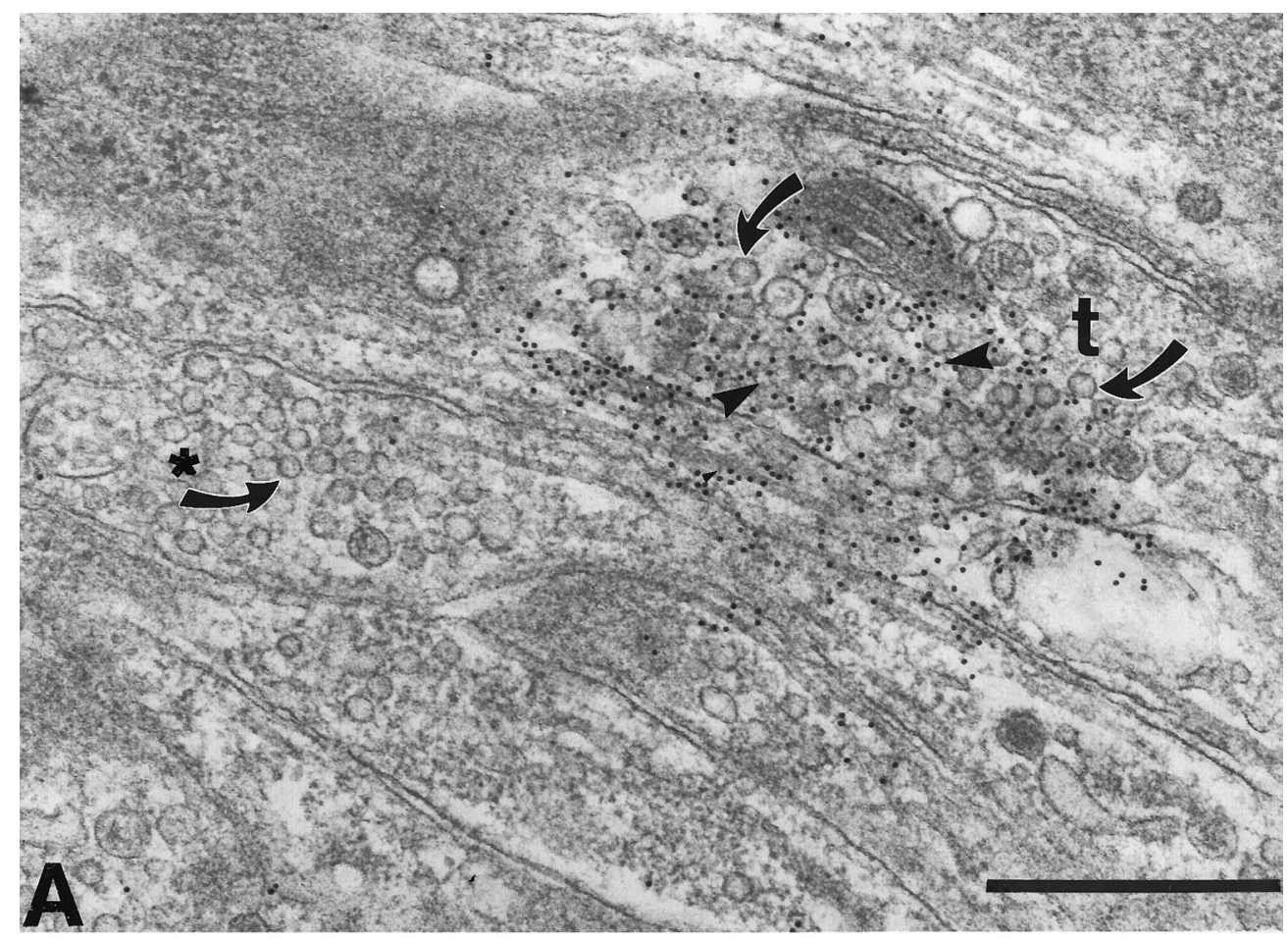

Figure 2. Glutamate-immunoreactive varicosities can be detected by electron microscopy in myenteric ganglia. $A$, Small, clear, round synaptic vesicles (arrow) are present in all glutamateimmunoreactive nerve terminals $(t)$. The black dots (arrowhead) are gold particles $(10 \mathrm{~nm})$, which identify the axon as containing high levels of glutamate. A second terminal $\left(^{*}\right)$ also contains clear, round synaptic vesicles (arrow) but few gold particles. Note that there is some diffusion of the amino acid. $B$, Varicosities in which large, dense-cored vesicles (arrow) predominate are not labeled by antibodies to glutamate. Scale bar, 0.5 $\mu \mathrm{m}$.

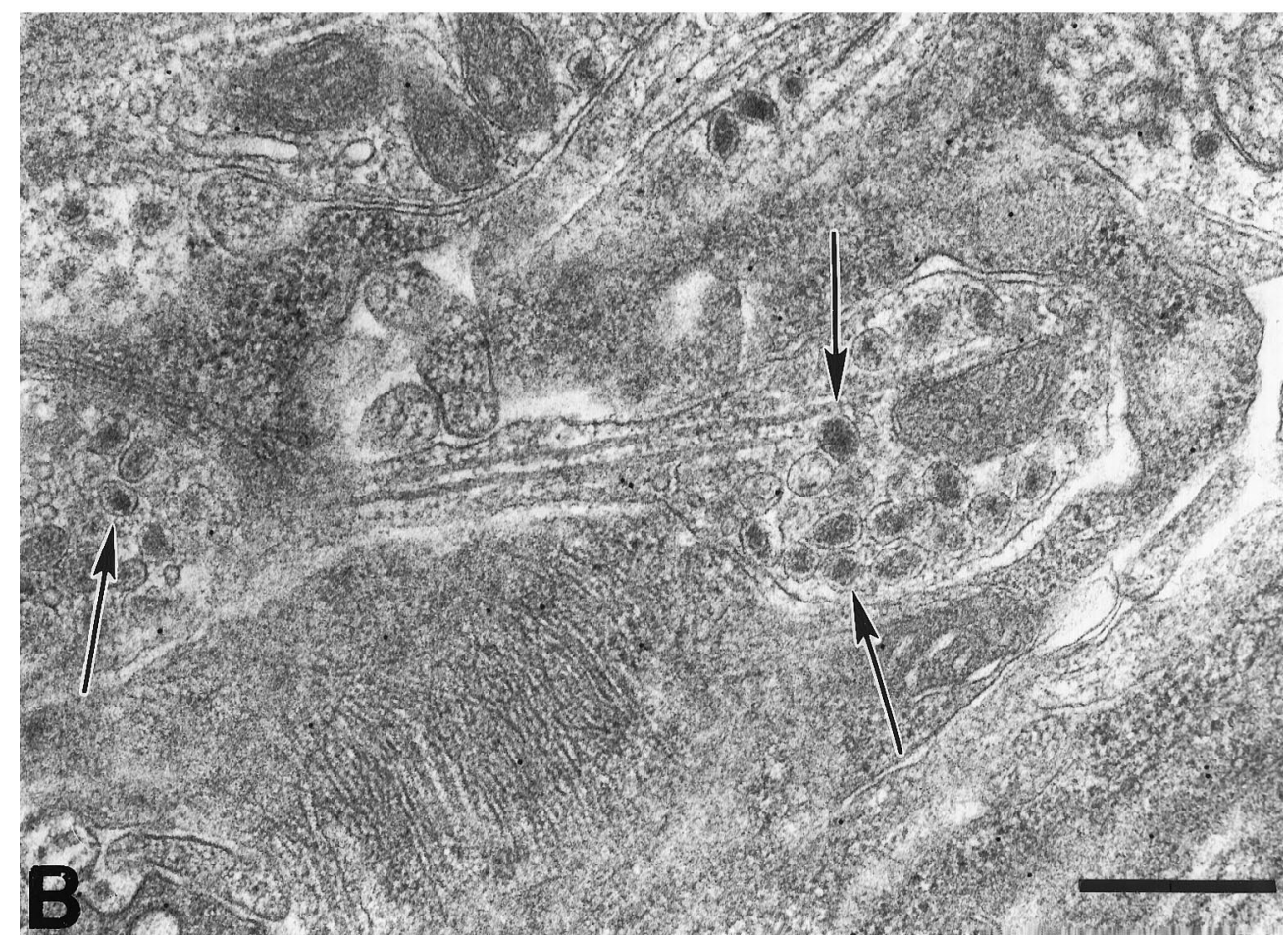

substance $\mathrm{P}$ (Table 2). Almost all of the guinea pig glutamateimmunoreactive myenteric neurons exhibited Dogiel type II morphology (Fig. 1 $A$ ); nevertheless, only $\sim 10 \%$ of them co-stored calbindin, which is a marker associated with $\sim 70 \%$ of Dogiel type II neurons (Costa et al., 1996).

Glutamate-immunoreactive axons were abundant in each plexus of both guinea pig and rat. Within ganglia, processes were thin and varicose (Fig. $1 A, F$ ). These varicose axons occasionally formed baskets around neuronal cell bodies. In addition, thicker, nonvariose fibers seemed to enter ganglia from a connective, traverse ganglia without branching and leave in a different connective (Fig. $1 B, D$ ). These apparent fibers in transit were most commonly located at the periphery of the ganglia through which they passed. Glutamate-immunoreactive axons were also observed in the circular muscle layer, mucosa, and surrounding blood vessels (not illustrated). To investigate whether glutamate immunoreactivity occurs in presynaptic terminals, we used postembedding electron microscopic immunocytochemistry with immunogold $(n=5)$ (van den Pol, 1991). Glutamateimmunoreactive axon terminals were observed in contact with 


\begin{tabular}{|c|c|c|c|c|c|}
\hline \multirow[b]{2}{*}{ Structure } & \multicolumn{2}{|c|}{$\begin{array}{l}\text { Immunogold distri- } \\
\text { bution }\end{array}$} & \multicolumn{2}{|c|}{$\begin{array}{l}\text { Dot distribution } \\
\text { (random) }\end{array}$} & \multirow[b]{2}{*}{$\chi^{2}$} \\
\hline & $n$ & & $n$ & $\%$ & \\
\hline \multicolumn{6}{|l|}{ Cellular distribution } \\
\hline Varicosities & 182 & 42 & 175 & 16 & $185.06^{*}$ \\
\hline Perikarya & 100 & 23 & 229 & 20 & 1.11 \\
\hline Neurites & 108 & 25 & 475 & 43 & 32.71 \\
\hline Gila & 48 & 10 & 236 & 21 & 21.77 \\
\hline Totals & 438 & 100 & 1115 & 100 & $\Sigma=240.6^{*}$ \\
\hline \multicolumn{6}{|c|}{ Subcellular distribution in varicosities } \\
\hline Synaptic vesicles & 182 & 65 & 57 & 26 & $162.75^{*}$ \\
\hline $\begin{array}{l}\text { Large, dense- } \\
\text { core vesicles }\end{array}$ & 13 & 5 & 21 & 9 & 7.26 \\
\hline Mitochondria & 25 & 9 & 23 & 11 & 0.83 \\
\hline Cytosol & 55 & 19 & 91 & 42 & 32.0 \\
\hline Filaments & 5 & 2 & 6 & 3 & 0.57 \\
\hline Plasma & 0 & 0 & 13 & 6 & 17.0 \\
\hline \multicolumn{6}{|l|}{ Membrane } \\
\hline Vacuoles & 0 & 0 & 8 & 4 & 10.0 \\
\hline Totals & 280 & 100 & 281 & 100 & $\Sigma=230.41^{*}$ \\
\hline
\end{tabular}

The structures underlying immunogold particles were identified, and the number of particles associated with each structure was counted. The distribution of immunogold particles was then compared, by means of a $\chi^{2}$ test, with that of a grid of dots superimposed over the same micrographs. The distribution of the dots was taken as that expected for a random distribution of label. The distribution of immunogold particles over cellular structures was not random $(p<0.001)$. Because varicosities were labeled, the distribution of immunogold particles over subcellular structures within varicosities was compared with that of a random distribution of dots. The distribution of immunogold particles over subcellular structures within the varicosities was not random $(p<0.001)$.

*Significantly more than expected; $p<0.001$.

dendrites of postsynaptic cells (Fig. $2 A$ ). To determine whether the location of gold particles over axonal varicosities was significant, the distribution of gold particles on immunostained grids was compared with that of an array of dots superimposed on the electron micrographs of the neuropil of the myenteric plexus. Although the dots were arrayed in a regular pattern, the pattern was random with respect to the structures in the micrographs. Structures under the dots were identified and scored, as were structures under the gold particles. The distribution of structures under the dots was compared with that under gold particles by means of a $\chi^{2}$ test, in which the dots served as the distribution that would have been expected if the gold particles had randomly precipitated over the tissue. Essentially no gold particles were found on control grids, incubated in the absence of primary antibodies (data not illustrated). The distribution of gold particles over cellular elements of the tissue differed significantly from that expected for a random array $(p<0.001)$ (Table 3 , cellular distrubution); furthermore, significantly more immunogold particles were found over axonal varicosities than could be accounted for by chance $(p<0.001)$. These glutamate-immunoreactive boutons contained populations of small (diameter, $\sim 50 \mathrm{~nm}$ ), clear, round synaptic vesicles. Although small numbers of densecored vesicles were also present in labeled terminals, the small, clear vesicles predominated. Because axonal varicosities were labeled by antibodies to glutamate, the subcellular distribution of immunogold particles within the labeled varicosites was also analyzed (Table 3, subcellular distribution in varicosities). The number of immunogold particles over small, clear syanptic vesicles was significantly greater than that expected for a random distribution $(p<0.001)$, whereas that over the large, dense-cored vesicles was not. The subset of varicosities in which large, dense-cored vesicles predominated was not labeled by antibodies to glutamate (Fig. 2B).

\section{Enteric neurons express AMPA and NMDA receptors}

The hypothesis that glutamate is an enteric neurotransmitter requires that enteric neurons express glutamate receptors. Immunocytochemistry was thus used to determine whether evidence of the expression of these receptors could be obtained. The immunoreactivities of both AMPA (Fig. 3) and NMDA (Fig. $4 A, B)$ receptors were detected on enteric neurons. In general, immunolabeling was cytoplasmic, filling the perikarya and occasionally the proximal dendrites of a subset of enteric neurons. In addition, the staining intensity of somata varied. Some were very intensely stained; others were more lightly stained. The cytoplasmic localization of the glutamate receptors in enteric neurons agrees with previous studies, which have visualized these receptors in fixed and permeabilized central neurons, using C-terminal antibodies (Petralia and Wenthold, 1992; Petralia et al., 1994a,b). At least part of the internal labeling may represent receptors in transport to and from the cell membrane (Wenthold et al., 1990).

Antibodies to the C-terminal portions of AMPA receptor subunits GluR1, GluR2/3, and GluR4 (Petralia and Wenthold, 1992) were used to identify immunocytochemically the neurons on which these receptor subunits are located (Table 1). More than half of the cells in the myenteric plexus that contained calbindin, a $\mathrm{Ca}^{2+}$-binding protein that has been used as a marker for $2 / \mathrm{AH}$ neurons (Iyer et al., 1988; Song et al., 1991) and is present in $\sim 25 \%$ of myenteric neurons (Costa et al., 1996), co-expressed GluR1 (Fig. 3G,H). The presence of GluR1 in cells that express calbindin is thus consistent with the idea that glutamate mediates 

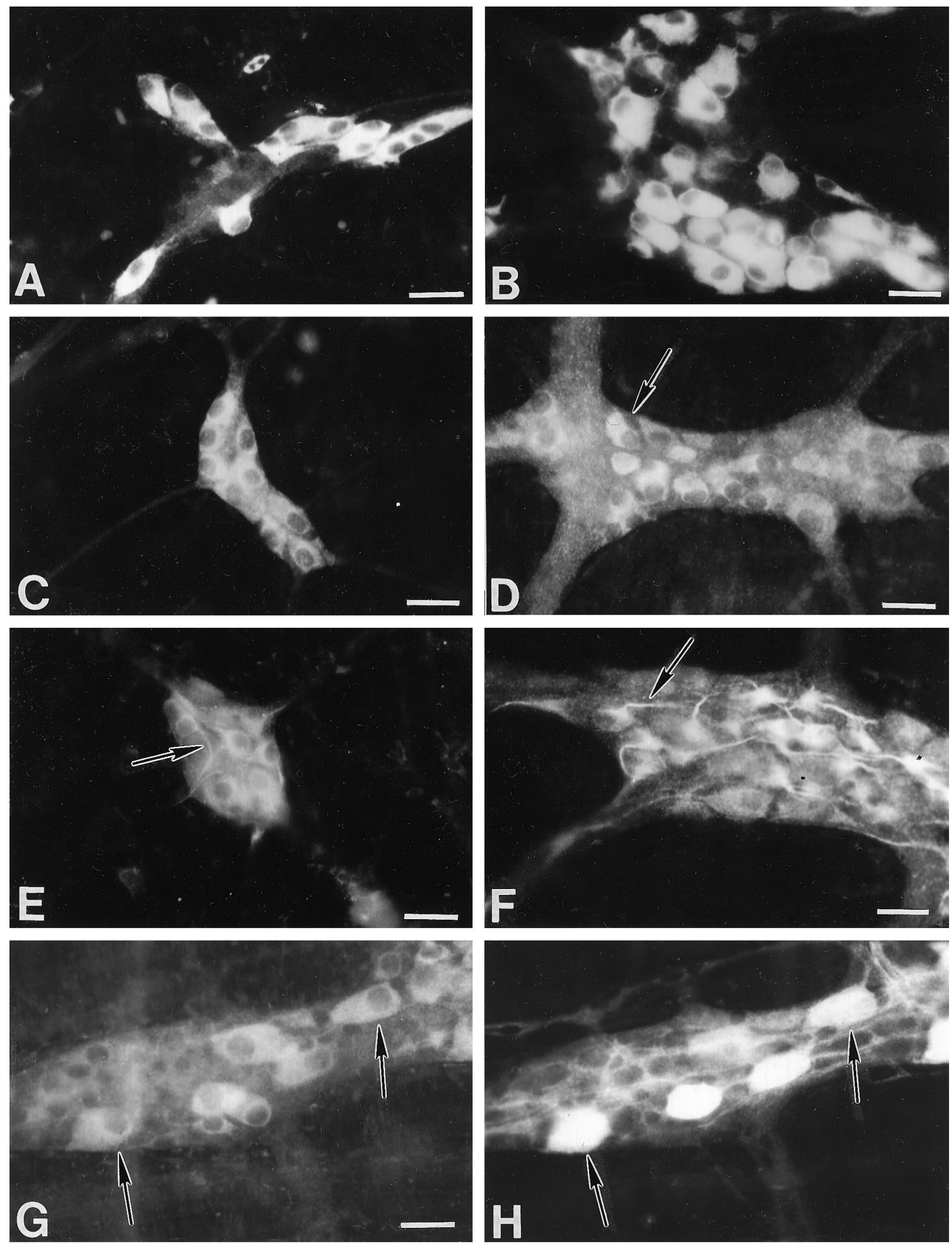

Figure 3. Differential distribution of AMPA receptor subunit immunoreactivity in the guinea pig small intestine. $A, B$, GluR1 immunoreactivity. A subset of neurons in the submucosal $(A)$ and myenteric $(B)$ plexus express GluR1 immunoreactivity. Immunoreactivity is concentrated in the cytoplasm. $C$, $D$, GluR2/3 immunoreactivity. The majority of neurons in the submucosal plexus $(C)$ express GluR2/3 immunoreactivity. A subset of neurons in the myenteric plexus $(D)$ expresses GluR2/3. These cells are small in size (arrow). $E, F$, GluR4 immunoreactivity. A subset of neurons in the submucosal $(E)$ and myenteric $(F)$ plexus express GluR4 immunoreactivity. Immunoreactivity is concentrated in the cytoplasm; however, proximal dendritic processes are also stained (arrow). $G, H$, GluR1 immunoreactivity $(G)$ is expressed by the majority of calbindin-immunoreactive myenteric neurons $(H$, arrow). Scale bar, $30 \mu \mathrm{m}$. 

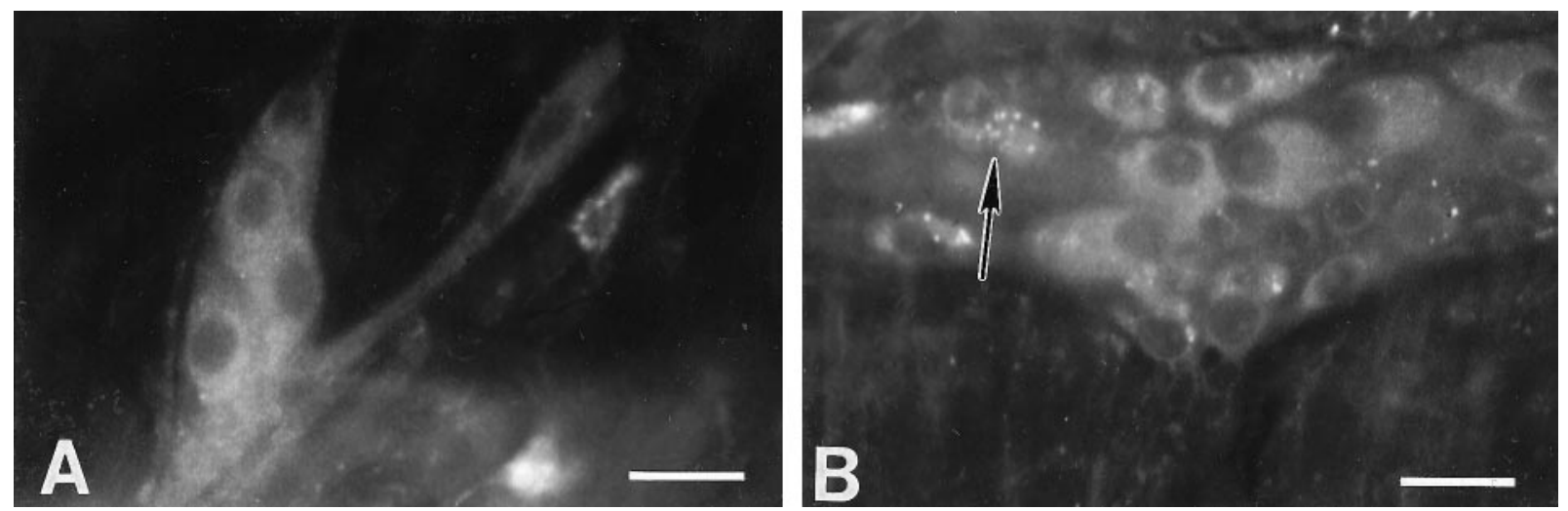

Figure 4. NMDA receptor subunit immunoreactivity in the guinea pig small intestine. $A, B$, The majority of neurons in the submucosal $(A)$ and myenteric $(B)$ plexus express NR2A/B immunoreactivity. Immunoreactivity is generally diffuse within labeled cells; however, labeled puncta are also observed (arrow).

synaptic transmission in a subset of $2 / \mathrm{AH}$ neurons. Calbindinimmunoreactive neurons did not contain GluR2/3 or GluR4 immunoreactivity (Table 2); however, the immunoreactivity of these subunits was encountered in other subsets of myenteric neurons. The GluR2/3 subunits were observed in small cells and were confined to the cell bodies of these neurons (Fig. 3D). GluR2/3immunoreactive neurons co-expressed ChAT, nitric oxide synthase (NOS), and calretinin immunoreactivities. Although many ChAT-immunoreactive neurons did not contain GluR2/3, every NOS- and calretinin-immunoreactive cell was GluR2/3immunoreactive. NOS- and calretinin-immunoreactive neurons account for $\sim 19$ and $26 \%$, respectively, of all myenteric neurons (Furness et al., 1994; Costa et al., 1996). GluR4-immunoreactive neurons (Fig. $3 F$ ) were larger than those that contained GluR2/3, and GluR4 immunoreactivity extended into the processes of these neurons. In contrast to GluR2/3, GluR4 immunoreactivity was never seen in NOS-immunoreactive neurons. ChAT immunoreactivity marked $100 \%$ of GluR4-immunoreactive neurons, and a large subset was also calretinin-immunoreactive. Submucosal neurons that contained calbindin were also GluR1-immunoreactive (Fig. $3 A$ ); however, in contrast to their counterparts in the myenteric plexus, these cells also expressed GluR2/3 immunoreactivity (Table 2, Fig. $3 C$ ). In the CNS, AMPA receptors are impermeable to $\mathrm{Ca}^{2+}$ in cells that express the GluR2 subunit (Hollmann et al., 1991; Vodyanoy, 1995); therefore, the calbindin-containing neurons of the myenteric plexus may express AMPA receptors that are permeable to $\mathrm{Ca}^{2+}$. GluR2/3 immunoreactivity was also seen in ChAT- and noncholinergic vasoactive intestinal polypeptide (VIP)-immunoreactive neurons. Because ChAT- and VIPimmunoreactive neurons represent $\sim 50$ and $45 \%$, respectively, of all submucosal neurons (Furness et al., 1984), GluR2/3 immunoreactivity seems to be found in the perikarya of almost all submucosal neurons. A subset of neurons in the submucosal plexus also expressed GluR4 immunoreactivity (Fig. 3E). Whereas many ChAT-immunoreactive neurons did not contain GluR4, every VIP-immunoreactive cell was GluR4-immunoreactive.

Antibodies to the C-terminal portions of NMDA receptor subunits NR1 and NR2A/B (Petralia et al., 1994a,b) were used to identify immunocytochemically the neurons on which these receptors are located (Table 1). NR1 and NR2A/B immunoreactivities were found in the perikarya of submucosal and myenteric neurons in all regions of the guinea pig bowel (Fig. $4 A, B$ ). Almost all enteric neurons expressed the immunoreactivities of the NMDA receptor

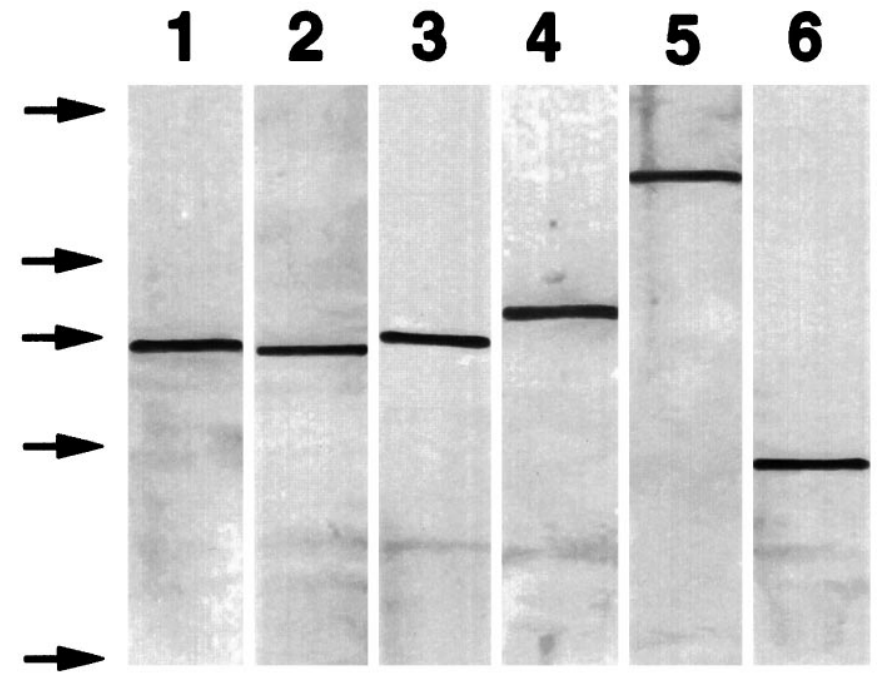

Figure 5. Immunostaining of Western blots of guinea pig LMMP with antibodies to GluR1 (lane 1), GluR2/3 (lane 2), GluR4 (lane 3), NR1 (lane 4), NRA/B (lane 5), and EAAC1 (lane 6). Forty micrograms of protein were applied to each lane. Arrows indicate positions of molecular weight standards myosin, $\beta$-galactosidase, phosphorylase B, BSA, and ovalbumin. Lanes 1-6 were done on separate gels, and the positions of the bands cannot be compared directly.

subunits NR1 and NR2A/B. AMPA receptor subunits were more selective in their distribution.

AMPA and NMDA receptor subunits were also detected in Western blots of crude membrane fractions from rat cortex and preparations of guinea pig LMMP. Immunoblot analysis of membranes from LMMP with antibodies to GR1, GR2/3, and GR4 detected a $\sim 93 \mathrm{kDa}$ protein (Fig. 5). Antisera to NR1 recognized a $\sim 101 \mathrm{kDa}$ protein, and antisera to NR2A/B recognized a $\sim 159 \mathrm{kDa}$ protein (Fig. 5). These results were consistent for glutamate receptor subunits (Hollman, 1997).

\section{Glutamate depolarizes enteric neurons}

Intracellular records were obtained from guinea pig myenteric neurons (Erde et al., 1985) to determine whether, as the immunocytochemical data outlined above suggest, these cells respond to glutamate and related agonists. Agonists were ap- 


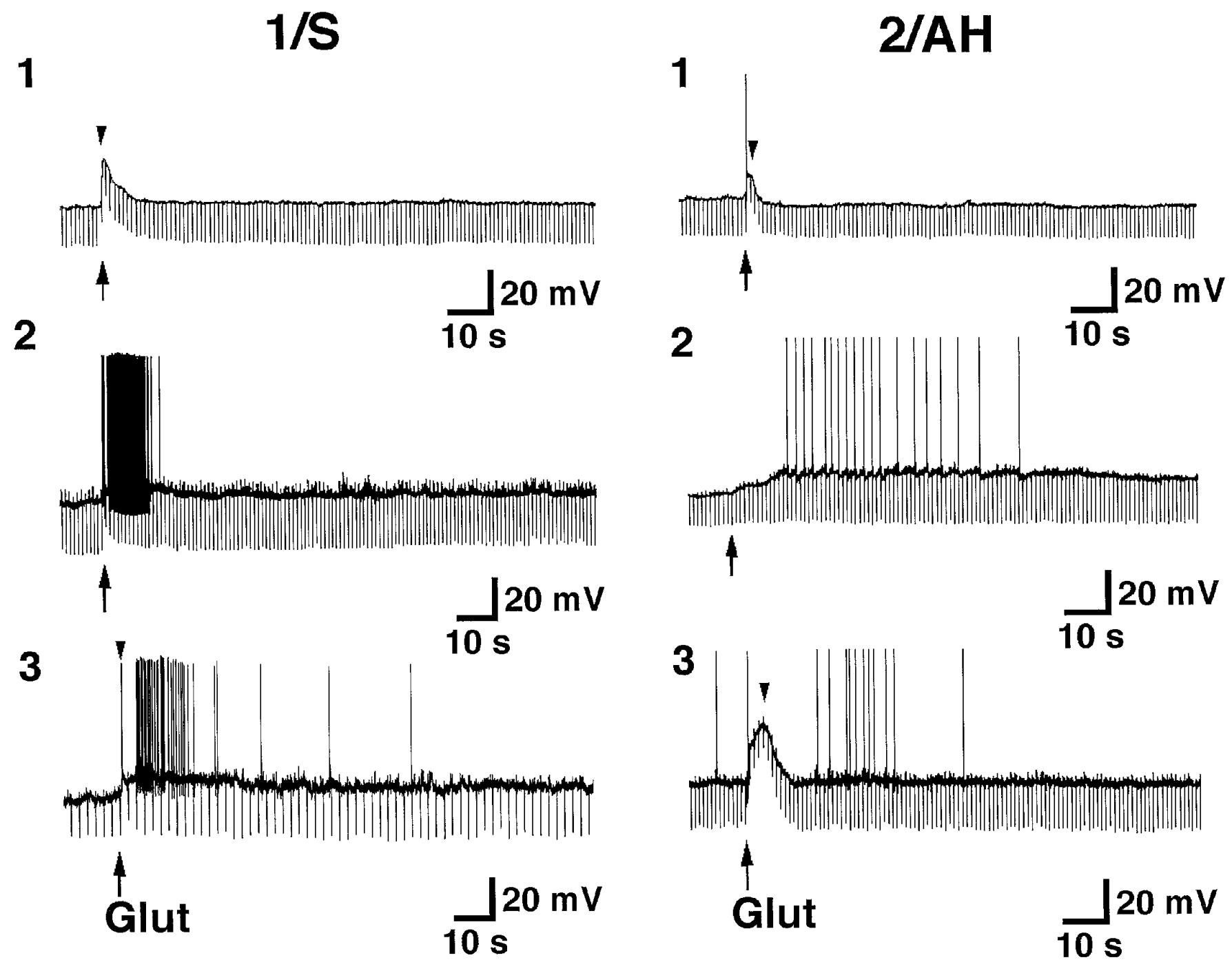

Figure 6. Glutamate (Glut) depolarizes $1 / \mathrm{S}$ and 2/AH myenteric neurons. Fast- and slow-depolarizing responses to glutamate are observed in 1/S and 2/AH cells. The downward deflections represent the electrotonic responses to the injections of hyperpolarizing current pulses. 1, Application of glutamate (arrow) induces a transient depolarization (fast response; arrowhead) that is associated with a decrease in input resistance (reflected by a decline in the amplitude of electrotonic potentials). Note that the $2 / \mathrm{AH}$ cell spikes during the fast response. 2, Microejection of glutamate leads to a prolonged membrane depolarization (slow response) associated with an increase in action potential activity. 3, Application of glutamate induces a biphasic depolarizing response, consisting of an initial fast response (arrowhead) and a partial recovery of the membrane potential, followed by a slow response. The cells discharge action potentials during the fast and slow response. For $1 / \mathrm{S}$ cells, resting membrane potential $(\mathrm{RMP})=-47,-42$, and $-49 \mathrm{mV}$; for $2 / \mathrm{AH}$ cells, $\mathrm{RMP}=-58,-61$, and $-56 \mathrm{mV}$.

plied by ejection with pressure from micropipettes (Wood and Mayer, 1979; Takaki et al., 1985). Cells were classified physiologically as $2 / \mathrm{AH}$ or $1 / \mathrm{S}$ according to established criteria (Gershon et al. 1994; Schutte et al., 1995). These criteria are for 2/AH neurons: (1) a prolonged hyperpolarizing afterpotential (the $\mathrm{AH}) ;(2)$ a prominent $\mathrm{Ca}^{2+}$ shoulder on the falling phase of the action potential (which is tetrodotoxin-resistant); (3) the failure of the cells to spike repetitively when injected with depolarizing current pulses; and (4) the absence of anodal break excitation. In contrast, $1 / \mathrm{S}$ cells lack a $\mathrm{Ca}^{2+}$ shoulder, spike repetitively throughout prolonged depolarizing current pulses, display anodal break excitation at the offset of intraneuronally injected hyperpolarizing current pulses, and do not exhibit a long-lasting membrane hyperpolarization after an action potential. In practice, some of the properties of $2 / \mathrm{AH}$ cells can be transiently masked if cells are excited at the time they are impaled. For example, when cells receive slow EPSPs, which may occur spontaneously, the $\mathrm{AH}$ is inhibited, cells fire repetitively, and they exhibit anodal break excitation. An excited $2 / \mathrm{AH}$ neuron could potentially be misclassified as $1 / \mathrm{S}$ if one were to rely heavily on criteria subject to masking (Schutte et al., 1995). The one criterion that is never masked is the $\mathrm{Ca}^{2+}$ shoulder on the falling phase of the action potential; therefore, this property was the most important of those investigated. No cell was considered $2 / \mathrm{AH}$ unless a $\mathrm{Ca}^{2+}$ shoulder was demonstrated, and all of the cells in which it was clearly absent were classified as $1 / \mathrm{S}$.

Depolarizing responses to glutamate were observed in the majority of impaled enteric neurons (Fig. 6). Both $1 / \mathrm{S}$ and 2/AH neurons responded to glutamate, although more such responses were obtained from $2 / \mathrm{AH}$ cells, because they tended to be impaled most often. The responses seen were either 
Table 4. Characteristics of responses of myenteric neurons to glutamate

\begin{tabular}{|c|c|c|c|c|c|c|c|c|c|c|}
\hline \multirow[b]{2}{*}{ Response } & \multicolumn{5}{|c|}{ 2/AH neurons } & \multicolumn{5}{|c|}{ 1/S Neurons } \\
\hline & $n$ & $\begin{array}{l}\text { Amplitude } \\
(\mathrm{mV})\end{array}$ & $\begin{array}{l}\text { Time to } \\
\text { peak }(\mathrm{sec})\end{array}$ & $\begin{array}{l}\text { Duration } \\
(\mathrm{sec})\end{array}$ & $\begin{array}{l}\text { Change in } \\
R_{\text {in }}(\%)\end{array}$ & $n$ & $\begin{array}{l}\text { Amplitude } \\
(\mathrm{mV})\end{array}$ & $\begin{array}{l}\text { Time to } \\
\text { peak }(\mathrm{sec})\end{array}$ & $\begin{array}{l}\text { Duration } \\
(\mathrm{sec})\end{array}$ & $\begin{array}{l}\text { Change in } \\
R_{\text {in }}(\%)\end{array}$ \\
\hline Fast only & 6 & $13.6 \pm 3.2$ & $1.5 \pm 0.4$ & $12.4 \pm 2.0$ & $-7.8 \pm 4.0$ & 2 & $5.0 \pm 1.0$ & $1.8 \pm 0.1$ & $6.1 \pm 0.3$ & $-16.2 \pm 5.4$ \\
\hline Slow only & 24 & $8.8 \pm 0.8$ & $7.6 \pm 1.8$ & $66.9 \pm 8.9$ & $14.1 \pm 5.7$ & 4 & $7.6 \pm 0.8$ & $2.6 \pm 0.2$ & $43.5 \pm 7.3$ & $9.2 \pm 1.9$ \\
\hline Fast + slow: fast & 14 & $21.4 \pm 3.1$ & $1.8 \pm 0.3$ & $6.7 \pm 0.9$ & $-19.2 \pm 7.5^{*}$ & 6 & $22.5 \pm 5.3$ & $1.4 \pm 0.3$ & $4.5 \pm 1.1$ & $-25.3 \pm 8.1^{*}$ \\
\hline Fast + slow: slow & & $12.1 \pm 3.4$ & $28.7 \pm 6.1$ & $83.7 \pm 10.9$ & $21.0 \pm 12.0$ & & $10.8 \pm 2.6$ & $9.3 \pm 2.1$ & $75.9 \pm 11.8$ & $12.9 \pm 10.8$ \\
\hline No effect & 18 & & & & & 4 & & & & \\
\hline
\end{tabular}

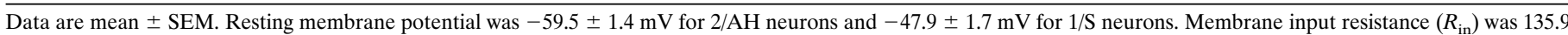

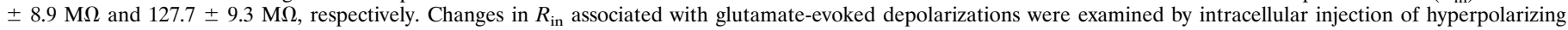
current pulses and by measuring the amplitude of the resulting electrotonic potentials.

*Significantly different from control $(p<0.05)$.

monophasic fast, monophasic slow, or biphasic. The characteristics of the responses to glutamate and the frequency with which they were encountered are summarized in Table 4. A third component, consisting of a highly delayed depolarizing response $(\sim 70 \mathrm{sec})$, associated with an increase in input resistance, was recorded in two $2 / \mathrm{AH}$ neurons. Because of the extremely low frequency of occurrence of this response, it was not investigated further. The fast component of the response to glutamate consisted of a rapidly developing depolarization associated with a fall in membrane input resistance (Table 4). The slow component appeared later, was longer-lasting, and was not associated with a consistent change in input resistance. The time courses of the two components partially overlapped, significantly increasing the amplitude of the initial component in cells that displayed biphasic responses. The glutamateinduced depolarizations were concentration-dependent, in that the amplitude of the responses increased as the duration of the pressure pulse used for microejection was increased from 50 to $500 \mathrm{msec}$ (Fig. 7). Responses to glutamate desensitized in both 1/S and 2/AH neurons and declined in amplitude unless successive applications were separated by intervals of $10 \mathrm{~min}$ (data not illustrated).

\section{Fast responses to glutamate are mediated by postsynaptic AMPA receptors}

Activation of presynaptic or postsynaptic receptors or both could potentially account for fast responses to glutamate. To examine the locus of glutamate-induced fast depolarizations, we analyzed the fast response in the presence of tetrodotoxin and low-Ca ${ }^{2+} /$ high- $\mathrm{Mg}^{2+}$ solutions. Neither tetrodotoxin (300 $\mathrm{nM} ; n=4)$, nor low $-\mathrm{Ca}^{2+} /$ high $-\mathrm{Mg}^{2+}(1.0 / 15.0 \mathrm{mM} ; n=3)$ solutions significantly affected fast responses to glutamate (Fig. 8 ). These data indicate that fast responses to glutamate are not secondary effects of the release of another neurotransmitter but are directly mediated by glutamate-responsive receptors of the impaled neurons.

Pharmacological studies were conducted to characterize the receptor(s) that mediate the fast component of the glutamate response. Receptors were identified by adding antagonists to the superfusing solution. The antagonists studied were either to glutamate receptor subtypes or, as controls, to other receptors that are known to be capable of mediating fast depolarizing responses. The non-NMDA antagonists selected for this study, CNQX and DNQX, were chosen because each has been well characterized in previous studies (van den Pol et al., 1990; McGehee et al., 1995). Concentrations used were comparable with those used by other investigators and found to be effective in blocking non-NMDA-mediated transmission in the CNS. The compounds were also applied in preliminary studies to find a concentration range that did not affect the resting membrane potential of $2 / \mathrm{AH}$ neurons. At concentrations of $\mathrm{CNQX} \geq 30$ $\mu \mathrm{M}$ cells were depolarized. DNQX is more potent than CNQX and was found to exert no effect on membrane potential at 20 $\mu \mathrm{M}$. Both compounds were therefore used at concentrations $\leq 20 \mu \mathrm{M}$. Selective agonists were applied by microejection, as above. Data were obtained from 2/AH neurons, because these cells were impaled with the highest frequency. An initial application of glutamate was used to determine whether the cell displayed a fast response to glutamate. Cells that did not respond with a fast reponse to glutamate were not studied further, because a preliminary investigation revealed that these cells also failed to respond to the non-NMDA agonist AMPA.

The fast but not the slow response to glutamate was mimicked by AMPA in seven of seven neurons (Fig. 9). Pressure ejection of AMPA produced a membrane depolarization that reached maximal amplitude $(20.3 \pm 1.6 \mathrm{mV})$ within $0.7 \pm 0.1 \mathrm{sec}$ after application and returned to the pre-AMPA level within $5.7 \pm 2.2$ sec. The AMPA-induced depolarizations were accompanied by a decrease in input resistance of $11.8 \pm 1.3 \%$. The AMPA response was inhibited by adding the non-NMDA antagonist CNQX ( $n=$ 3 ) or DNQX $(n=4)$ to the superfusing medium (Fig. $9 A)$. In contrast, the similar applications of the nicotinic antagonist hexamethonium $(n=3$; Fig. $9 B)$, the ATP antagonist suramin $(n=2$; $100 \mu \mathrm{M})$, or the $\mathrm{GABA}_{\mathrm{A}}$ antagonist bicuculline $(n=2 ; 50 \mu \mathrm{M})$ failed to influence responses to AMPA. As a control, fast responses were evoked by nicotine to evaluate the effect of the non-NMDA antagonists (CNQX and DNQX) on nicotinic receptors. Fast responses to nicotine were not affected by the nonNMDA antagonists ( $n=4$; Fig. $9 A)$; they were blocked, as expected, by hexamethonium $(n=4$; Fig. $9 B)$. In a like manner, fast responses to glutamate were inhibited by the non-NMDA antagonists $(n=3$; Fig. $10 A)$ but not by hexamethonium $(n=3$; data not illustrated). Fast responses of $2 / \mathrm{AH}$ neurons to glutamate, therefore, are pharmacologically equivalent to responses of these cells to AMPA and thus are probably mediated by nonNMDA receptors.

Because the non-NMDA antagonists do not distinguish between the kainate and AMPA receptor subtypes (Harris, 1995), experiments were performed to determine whether the fast response to glutamate is mediated by kainate or AMPA receptors. AMPA receptors are known to desensitize readily, a process that 


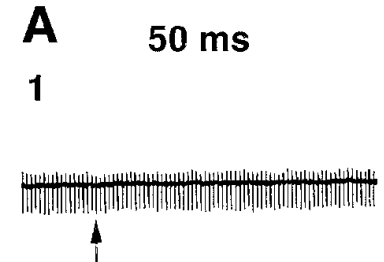

2

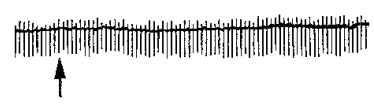

3

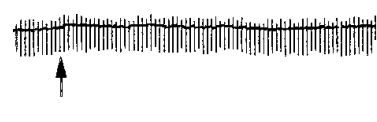

$100 \mathrm{~ms}$
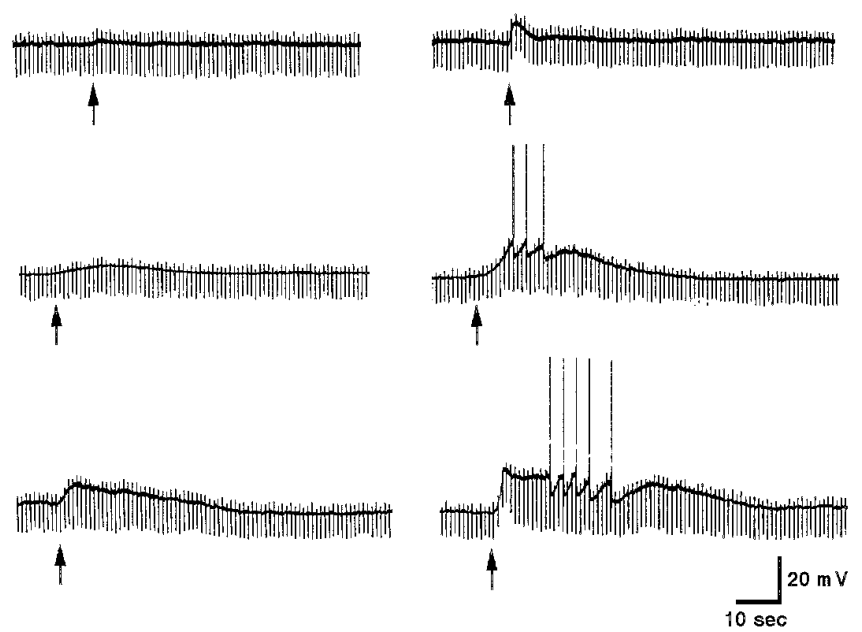

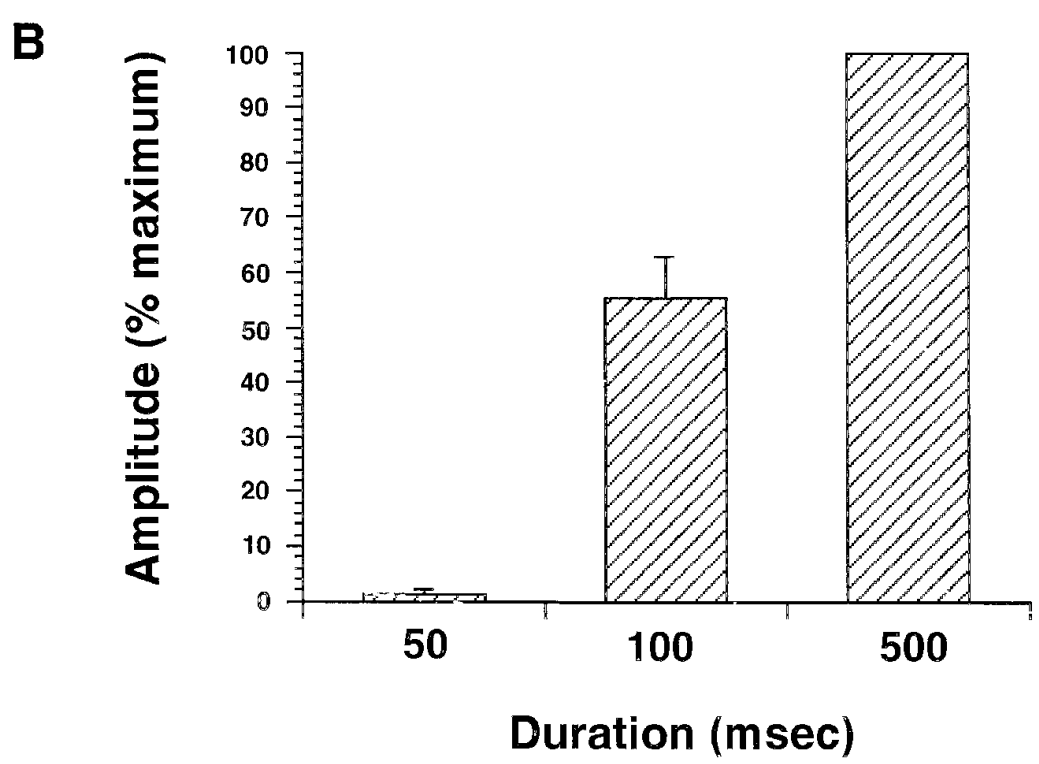

Figure 7. Concentration dependence of glutamate-mediated depolarizations. A, Glutamate was pressure-applied (arrow) at the indicated pulse durations (in milliseconds). Responses were obtained from three different $2 / \mathrm{AH}$ cells (RMP $=-58,-61$, and $-56 \mathrm{mV}$, respectively). $B$, Summary of concentration dependence of glutamate-mediated slow depolarizations. Data are expressed as percentages of maximum control responses $(n=6)$.

is inhibited by cyclothiazide (Harris, 1995). We therefore analyzed the effect of exposure to cyclothiazide $(25 \mu \mathrm{M})$ on the responses of 2/AH neurons to glutamate or AMPA. At this concentration, cyclothiazide itself did not produce a change in the resting mem brane potential or input resistance. Addition of cyclothiazide to the superfusing medium, however, caused the amplitude and duration of fast depolarizations evoked either by glutamate ( $n=$ 4) or AMPA $(n=4)$ to increase (Fig. 10B). Superfusion of cyclothiazide induced a $45.3 \pm 7.5 \%$ increase in the amplitude and a $70.7 \pm 19.6 \%$ increase in the duration of the glutamate response over control. Cyclothiazide induced a $59.4 \pm 10.4 \%$ increase in the amplitude and a $91.6 \pm 34.2 \%$ increase in the duration of the AMPA response over control. This effect of cyclothiazide indicates that the compound inhibits the rapid desensitization of receptors responsible for mediating fast responses to glutamate and AMPA and thus supports the idea that fast responses to glutamate and AMPA are mediated by AMPA rather than kainate receptors.

\section{Slow responses to glutamate are mimicked by NMDA}

The slow response to glutamate was not affected by addition of non-NMDA antagonists to the superfusing solution (Fig. 11A); The possibility that slow responses to glutamate are mediated by NMDA receptors was therefore investigated. These studies were again performed with $2 / \mathrm{AH}$ neurons. Slow responses to glutamate were mimicked by applications of NMDA (Fig. $11 B, C)$. As is well known from studies of NMDA responses of CNS neurons (Ascher and Johnson, 1994), the effects of NMDA on enteric 2/AH neurons were best seen in low- $\mathrm{Mg}^{2+}$ or $\mathrm{Mg}^{2+}$-free solutions and in the presence of glycine (10.0 $\mu \mathrm{M})$. Glycine is a co-agonist at NMDA receptors, so that in the absence of activation at the glycine site, no activation at the 


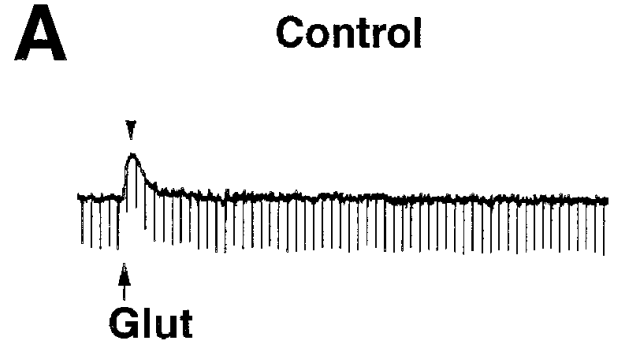

$+1 \mathrm{mM} \mathrm{Ca}^{2+}$ and $15 \mathrm{mM} \mathrm{Mg} \mathrm{g}^{2+} \mathrm{Krebs}$

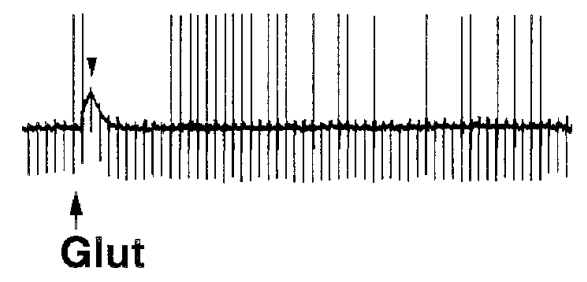

RMP $=-56 m V$

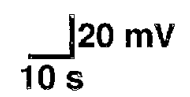

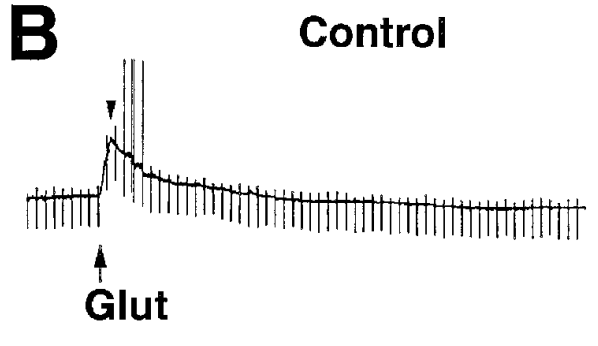

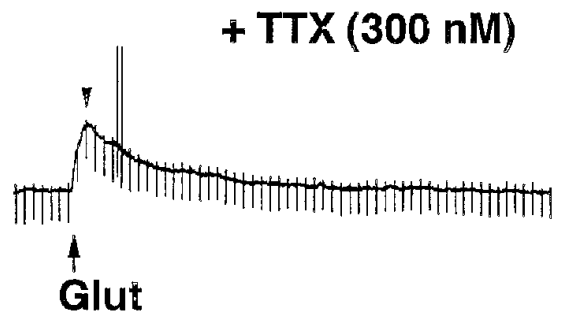

RMP $=-58 \mathrm{mV} \quad \frac{\sqrt{20} \mathrm{mV}}{10 \mathrm{~s}}$
Figure 8. Responses to glutamate (Glut) in myenteric neurons are direct and not attributable to the release of another neurotransmitter. 1, Microejection of glutamate onto a 2/AH neuron causes a fast response (arrowhead, Control) that is not inhibited by a low- $\mathrm{Ca}^{2+} /$ high- $\mathrm{Mg}^{2+}$-containing solution. The cell spikes repetitively in the low- $\mathrm{Ca}^{2+} /$ high- $\mathrm{Mg}^{2+}$-containing solution because a $\mathrm{Ca}^{2+}$-activated $\mathrm{K}^{+}$conductance contributes to the RMP of $2 / \mathrm{AH}$ cells, which become depolarized in the absence of $\mathrm{Ca}^{2+} .2, \mathrm{Su}-$ perfusion with TTX has no effect on glutamate-induced depolarizations recorded in a $2 / \mathrm{AH}$ neuron. Note that $\mathrm{Ca}^{2+}$ spikes are observed in the presence of TTX.
NMDA site may be possible, no matter how high a concentration of NMDA is present. NMDA evoked a slow depolarization $(61.5 \pm 17.7 \mathrm{sec}$ in duration) that reached maximal amplitude $(6.7 \pm 1.0 \mathrm{mV}) 8.9 \pm 4.3 \mathrm{sec}$ after the application of the compound. Input resistance was not consistently changed by applications of NMDA. Excitability of neurons was augmented during responses to NMDA. The NMDA response was inhibited by superfusion of either of two NMDA antagonists, AP5 (25-50 $\mu \mathrm{M}$; Fig. $11 B)$ or CPP $(100 \mu \mathrm{M}$; Fig. $11 C)$. The concentrations of these agents were selected as those that, when superfused by themselves in preliminary experiments, induced no change in resting membrane potential. AP5 also inhibited slow responses to glutamate and blocked the long-lasting increase in excitability that followed applications of glutamate (Fig. 11D). These observations are consistent with the idea that the NMDA receptor mediates the slow response to glutamate in enteric neurons; however, these observations are not consistent with the idea that NMDA receptor activation may mediate a slow EPSP in myenteric neurons. Slow EPSPs are more prolonged, and, in contrast to the NMDA-mediated response and the slow component of the response to glutamate, slow EPSPs are invariably associated with an increase in input resistance, which is attributable to a decrease in a $\mathrm{Ca}^{2+}$. activated $\mathrm{K}^{+}$conductance, a G-protein-dependent effect that is mediated by protein kinases (Bertrand and Galligan, 1995; Pan et al., 1997). It thus seems unlikely that NMDA receptors directly mediate slow synaptic events. The NMDA effect of glutamate, therefore, is more likely to be that of a modulator that potentiates the postsynaptic response to the endogenous slow transmitter. Alternatively, glutamate might presynaptically enhance the release of the endogenous slow transmitter.

\section{Glutamate contributes to fast synaptic transmission}

Because glutamate and AMPA each evoke a fast depolarization in enteric neurons, we investigated whether endogenous glutamate is a mediator of fast EPSPs. Fast EPSPs were evoked by stimulating interganglionic connectives and were recorded in 33\% (9 of 27) of 2/AH neurons. Fast EPSPs were also recorded in 1/S cells (2 of 2); however, these cells were infrequently impaled. Responses were identified as fast EPSPs, rather than antidromic action potentials, if their duration was relatively long $(>5 \mathrm{msec}$ ) and if their amplitude increased when the membrane potential was hyperpolarized. The average amplitude of the fast EPSP in 2/AH neurons was $5.5 \pm 0.81 \mathrm{mV}$, and the duration was $17.9 \pm 2.4 \mathrm{msec}$. These properties are very similar to those reported by other investigators (Grafe et al., 1979; Schutte et al., 1995). After obtaining a fast EPSP, the AMPA receptor antagonist DNQX was superfused, and the response was again elicited. DNQX inhibits fast responses to glutamate or AMPA (see above). DNQX markedly inhibited fast EPSPs recorded in 2/AH neurons (Fig. 12A). The amplitudes of fast EPSPs were reduced by DNQX to $35.5 \pm 15.2 \%$ of the control response in $2 / \mathrm{AH}$ cells $(n=5 ; p<0.05)$. The amplitudes of fast EPSPs in 2/AH neurons were also slightly reduced by 100 $\mu \mathrm{M}$ hexamethonium (to $73.9 \pm 9 \%$ of control); however, the degree of inhibition by DNQX was greater than that of hexamethonium (Fig. 12A; $p<0.05$ ). After experiments in which the effects of DNQX on fast EPSPs were studied, impaled neurons were marked by injection of Neurobiotin to ascertain whether the cell from which recordings were obtained actually expressed AMPA receptors. Neurons that responded to glutamate with a fast response and/or exhibited DNQX-inhibitable fast EPSPs (marked by the intracellular injection of Neurobiotin) were GluR1-immunoreactive (Fig. 12C,D), whereas those that failed to respond (also marked by Neurobiotin) were not (Fig. 12E,F). When applied to two 1/S cells, DNQX, even at the high concentration of $20 \mu \mathrm{M}$, only slightly affected the amplitude of the fast EPSP (Fig. 12B); however, the fast EPSPs in the $1 / \mathrm{S}$ neurons were essentially blocked by hexamethonium (100 $\mu \mathrm{M}$; Fig. 12B). These observations suggest that glutamate is a neurotransmitter that mediates fast excitatory transmission to myenteric $2 / \mathrm{AH}$ neurons. The partial effectiveness of hexamethonium in antagonizing fast EPSPs of 2/AH cells supports the idea that both acetylcholine (ACh) and glutamate are mediators of fast EPSPs in these neurons. 


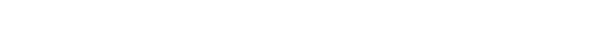

A

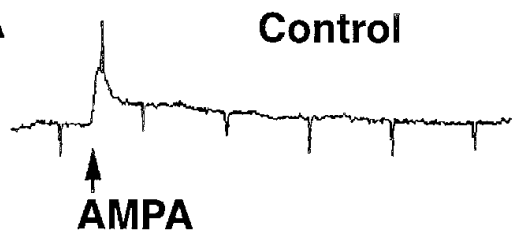

$+\operatorname{CNQX}(20 \mu \mathrm{M})$

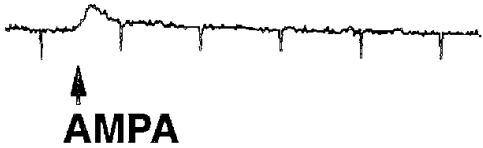

Wash

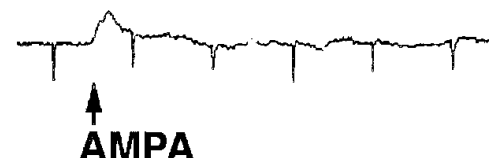

AMPA

RMP $=-58 \mathrm{mV}$
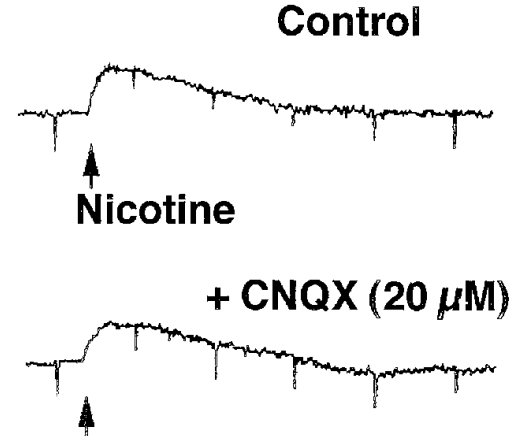

Nicotine

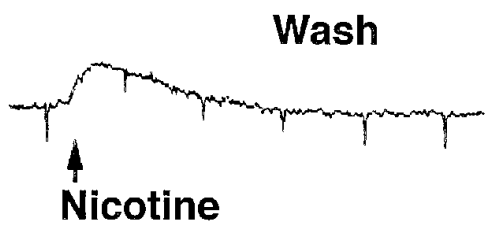

$\mathrm{RMP}=-58 \mathrm{mV}$ $\int_{2 \mathrm{~s}} 20 \mathrm{mV}$

B

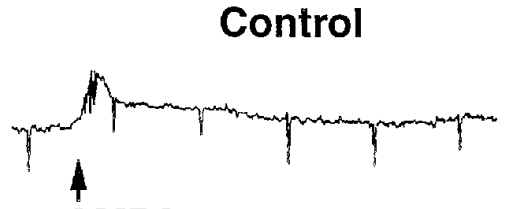

AMPA

+ Hexamethonium $(300 \mu \mathrm{M})$

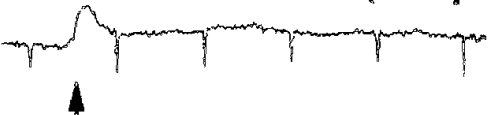

AMPA

Figure 9. Glutamate-induced fast-depolarizing postsynaptic AMPA receptors. $A, B$, Fast responses of enteric neurons to AMPA can be distinguished from those to nicotine. Similar fast responses are elicited by microejection of AMPA and nicotine in $1 / \mathrm{S}$ neurons (Control). The fast response to AMPA is antagonized by the nonNMDA antagonist CNQX $(A)$; however, CNQX does not affect responses to nicotine $(A)$. The nicotinic antagonist hexamethonium does not affect responses to AMPA $(B)$; however, it blocks responses to nicotine $(B)$. Recordings in $A$ and $B$ were obtained from different neurons.

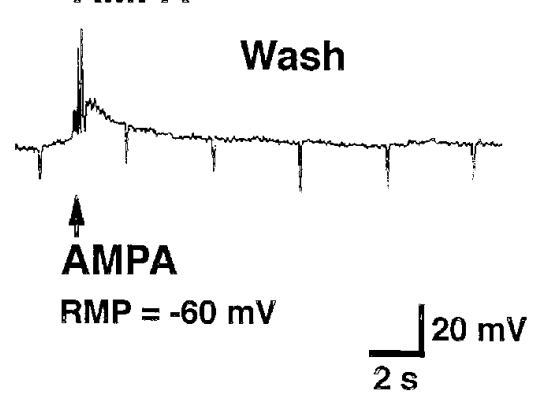

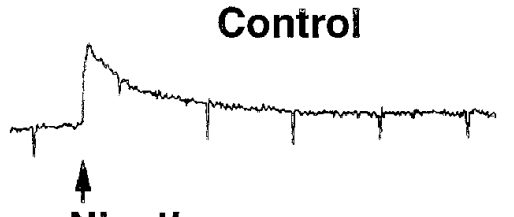

Nicotine

+ Hexamethonium (300 $\mu \mathrm{M})$
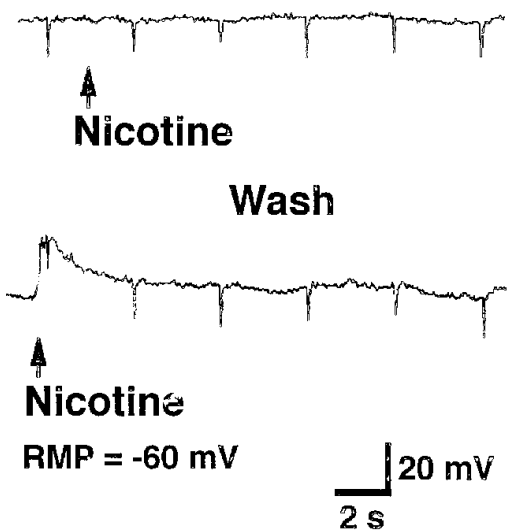

\section{Enteric neurons express glutamate transporters}

If glutamate is an excitatory neurotransmitter in the ENS, as the above observations imply, then an appropriate inactivating mechanism should be present to terminate its effects and to prevent desensitization of receptors. The ability of cyclothiazide to potentiate AMPA receptor-mediated responses to exogenous glutamate and AMPA implies that significant desensitization of these receptors occurs rapidly in the gut. In the
CNS, the synaptic actions of glutamate are inactivated by high-affinity glutamate transport (Tong and Jahr, 1994). Four high-affinity glutamate transporters have been identified in rat and/or human CNS tissue, including the neuronal subtypes EAAC1 and EAAT4 (Rothstein et al., 1994; Kanai et al., 1995) and the astroglial subtypes GLT-1 and GLAST (Rothstein et al., 1994; Storm-Mathisen et al., 1995). Antibodies to the neuronal transporter EAAC1 (Rothstein et al., 1994) were 

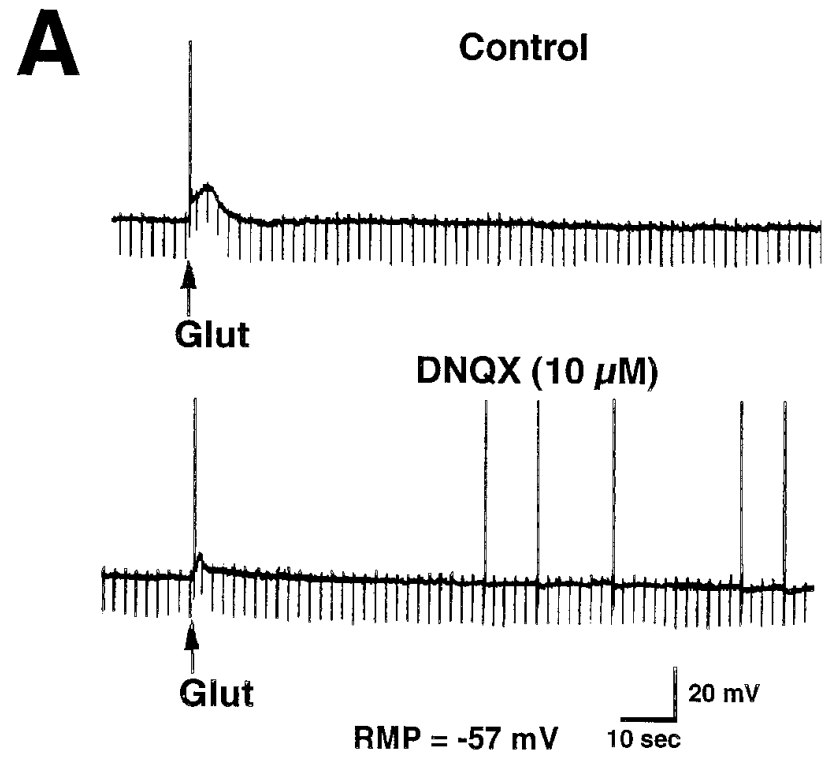

B
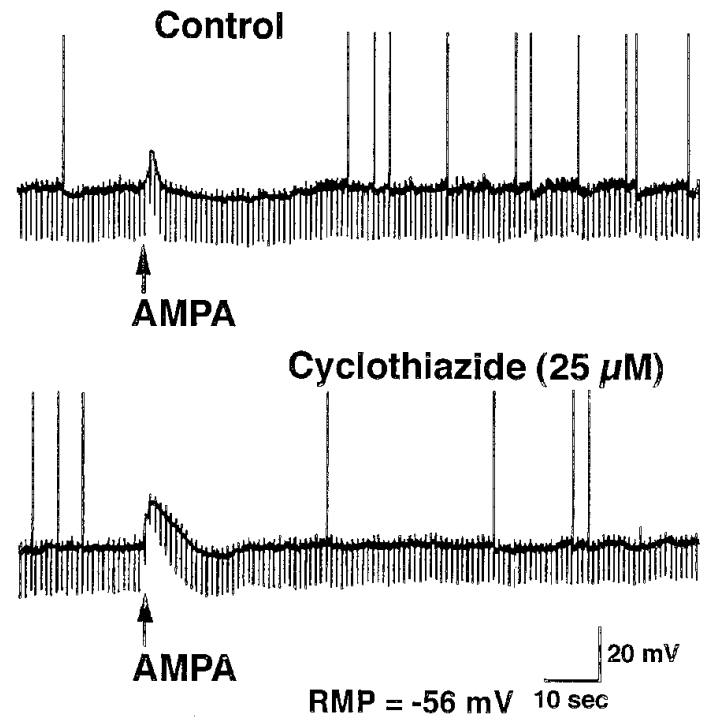

Figure 10. Fast responses to glutamate (Glut) are antagonized by DNQX. A, Fast responses to glutamate were recorded in a 2/AH neuron (Control). Superfusion with DNQX blocks the fast response. $B$, Desensitization of AMPA receptors limits AMPA-mediated fast responses. Superfusion with cyclothiazide, a selective blocker of AMPA receptor desensitization, potentiates fast responses to AMPA recorded in a 2/AH neuron.

therefore used to test immunocytochemically the hypothesis that this molecule is present in the ENS and to determine its location. In addition, the ability of two specific glutamate transport inhibitors, THA (100-300 $\mu \mathrm{M}$; Balcar et al., 1977) and PDC (50 $\mu \mathrm{M}$; Kanai et al. 1995), to potentiate fast responses to glutamate and fast EPSPs in 2/AH neurons was assessed. Fast EPSPs were examined in 2/AH neurons, because the previous experiments (see above) suggested that these responses are predominantly glutamatergic. After experiments in which the effects of THA or PDC on responses to glutamate and fast EPSPs were studied, impaled neurons were marked by injection of Neurobiotin to ascertain whether the cell from which recordings were obtained was actually EAAC1immunoreactive. Responses to glutamate $(n=7$; Fig. $13 A)$ and fast EPSPs in 2/AH neurons $(n=4$; Fig. $13 B)$ were each potentiated and prolonged by the glutamate uptake inhibitors. Superfusion of THA (at $300 \mu \mathrm{M}$, a concentration that caused no membrane depolarization), induced a $67.7 \pm 16.3 \%$ increase in the amplitude of the glutamate response over control. The potentiation of glutamate-mediated responses by THA persisted after washout of the drug (up to $50 \mathrm{~min}$ ) and was associated with spike activity. THA increased fast EPSP amplitude by $16.5 \pm 4.5 \%$ and duration by $27.6 \pm 3.4 \%$. PDC proved to be more difficult to analyze than THA. Some cells exposed to PDC became depolarized (by $\sim 10 \mathrm{mV}$ ) even in the absence of glutamate and spiked repetitively (data not illustrated). After the washout of PDC, membrane potential oscillated, and spontaneous bursts of action potentials persisted for about $1 \mathrm{hr}$. This discharge was abolished by DNQX $(5.0 \mu \mathrm{M}$; $n=3$ ) and thus could have been caused by the effects of spontaneous glutamate release in the preparations, unbuffered by reuptake. When encountered, the seizure-like activity evoked by PDC precluded the analysis of the effects of the compound on responses of myenteric neurons to exogenous glutamate or fast EPSPs. These observations support the idea that the EAAC1-mediated transport of glutamate is important, both in terminating the action of endogenous glutamate and in limiting the response of enteric neurons to exogenous glutamate. All of the cells in which enhanced responses to exogenous glutamate or potentiation of fast EPSPs were recorded contained EAAC1 immunoreactivity (Fig. 13C,D). In fact, all of the neurons that expressed calbindin immunoreactivity, the 2/AH cell marker, were found to be EAAC1-immunoreactive (Fig. 13E,F, see Table 2).

More neurons expressed EAAC1 immunoreactivity than that of calbindin. Because these cells were all morphologically Dogiel type II, the shape associated with 2/AH neurons (Erde et al., 1985; Bornstein et al., 1991), it seems likely that more 2/AH neurons express EAAC1 than calbindin, which is only present in $70-80 \%$ of 2/AH cells (Iyer et al., 1988; Song et al., 1991). The numbers of cells expressing EAAC1 were more than those expressing glutamate immunoreactivity, suggesting that the neuronal glutamate transporter is not confined in its expression to glutamatergic neurons (Table 2). EAAC1immunoreactive neurons were also found in the submucosal plexus (Fig. 14). As in the myenteric plexus, all of the neurons that expressed calbindin immunoreactivity were EAAC1immunoreactive (Fig. 14A,B). All neurons that expressed substance $\mathrm{P}$ immunoreactivity were also found to be EAAC1immunoreactive (Fig. 14C,D). EAAC1-immunoreactive fibers were observed to surround intestinal crypts (Fig. 14E,F). In addition, EAAC1 immunoreactivity was found in a subset of enterochromaffin cells, in which it was concentrated at the apex of the cells facing the intestinal lumen (Fig. 14F).

EAAC1 was also detected in Western blots of crude membrane fractions from rat cortex and preparations of guinea pig LMMP (Fig. 5). Immunoblot analysis of membranes from LMMP with antibodies to EAAC1 recognized a $\sim 64 \mathrm{kDa}$ protein. The apparent molecular weight of this protein was appropriate for the neuronal glutamate transporter (Rothstein et al., 1994). 
A
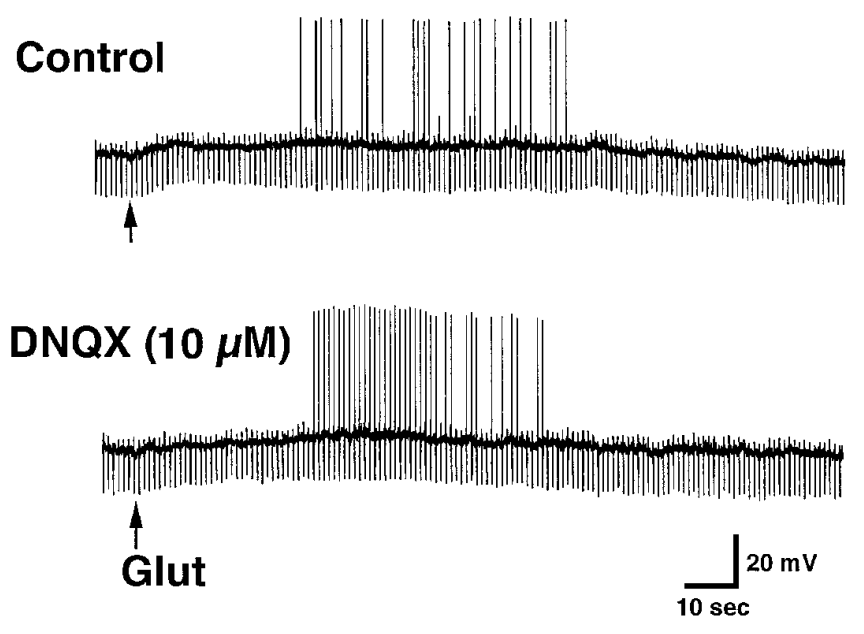

B

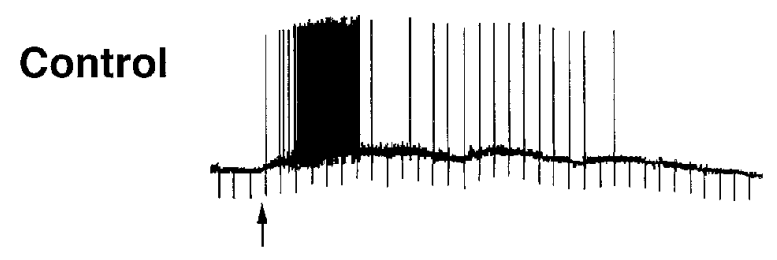

AP5 $(25 \mu \mathrm{M})$

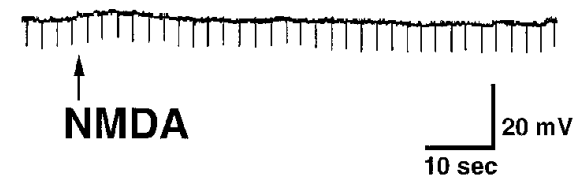

C

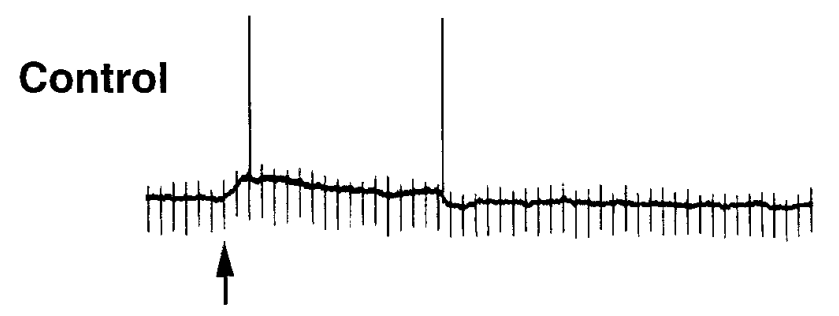

$\mathrm{CPP}(100 \mu \mathrm{M})$

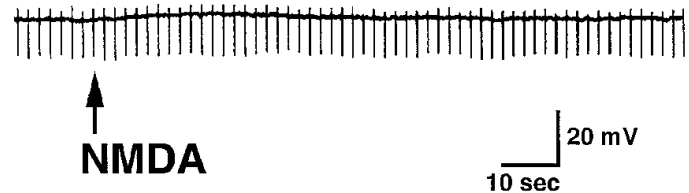

$\mathbf{D}$
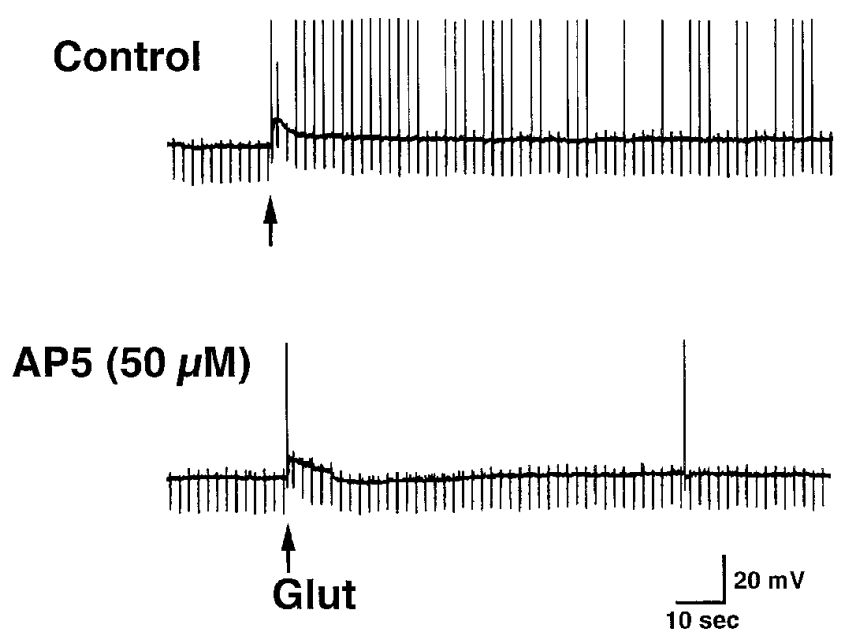

Figure 11. NMDA mimics the slow response to glutamate $(G l u t)$. $A$, Microejection of glutamate (arrow) onto a $2 / \mathrm{AH}$ neuron $(\mathrm{RMP}=-57 \mathrm{mV})$ leads to a prolonged membrane depolarization (slow response) associated with spike activity. Superfusion with DNQX does not block the glutamate-mediated slow response. $B$, Microejection of NMDA (arrow) onto a 2/AH neuron (RMP $=-58 \mathrm{mV}$ ) leads to a prolonged membrane depolarization associated with spike activity. The NMDA-mediated depolarization is blocked by AP5, an NMDA antagonist. $C$, The NMDA-mediated depolarization recorded in a $2 / \mathrm{AH}$ neuron (RMP $=-56 \mathrm{mV}$ ) is blocked by the NMDA antagonist CPP. Responses to NMDA in $B$ and $C$ were obtained in $\mathrm{Mg}^{2+}{ }^{-}$free $\mathrm{Krebs}$ solution that contained glycine $(10 \mu \mathrm{M})$. $D$, Glutamate evokes fast and slow responses (associated with spike activity) in a $2 / \mathrm{AH}$ neuron $(\mathrm{RMP}=-58 \mathrm{mV})$. Superfusion with AP5 inhibits only the slow response to glutamate.

\section{DISCUSSION}

Because many properties are known to be shared between the ENS and the CNS (Gershon et al., 1994), we thought that it was unlikely that glutamate, the major central excitatory transmitter, would play no role in the ENS. Previous reports had described evidence that was consistent with the idea that glutamate is an enteric neurotransmitter (Shannon and Sawyer, 1989; Wiley et al., 1991; Burns et al., 1994; Mannaioni et al.,
1994; Burns and Stephens, 1995; Rhoads et al., 1995), but earlier electrophysiological studies had failed to demonstrate a response of enteric neurons to glutamate (Mayer et al., 1982; Galligan and North, 1990). Experiments were thus undertaken to test the hypothesis that glutamate is an enteric neurotransmitter.

Subsets of glutamate-immunoreactive neurons were observed in each plexus but were more numerous in the submucosal plexus. In the guinea pig, all submucosal glutamate-immunoreactive neu-

Figure 12. Fast synaptic transmission in 2/AH neurons is attributable to activation of AMPA receptors. $A, B$, Fast EPSPs in 2/AH neurons are blocked by AMPA receptor antagonists. Effects of DNQX (left) and hexamethonium (right) on fast EPSPs recorded in $2 / \mathrm{AH}(A)$ and $1 / \mathrm{S}(B)$ neurons. DNQX blocks the fast EPSP recorded in a 2/AH neuron but only slightly reduces the amplitude of the fast EPSP recorded in a 1/S neuron. In contrast, the amplitude of the fast EPSP in a 2/AH neuron is only slightly reduced by hexamethonium; however, the fast EPSP recorded in (Figure legend continues) 

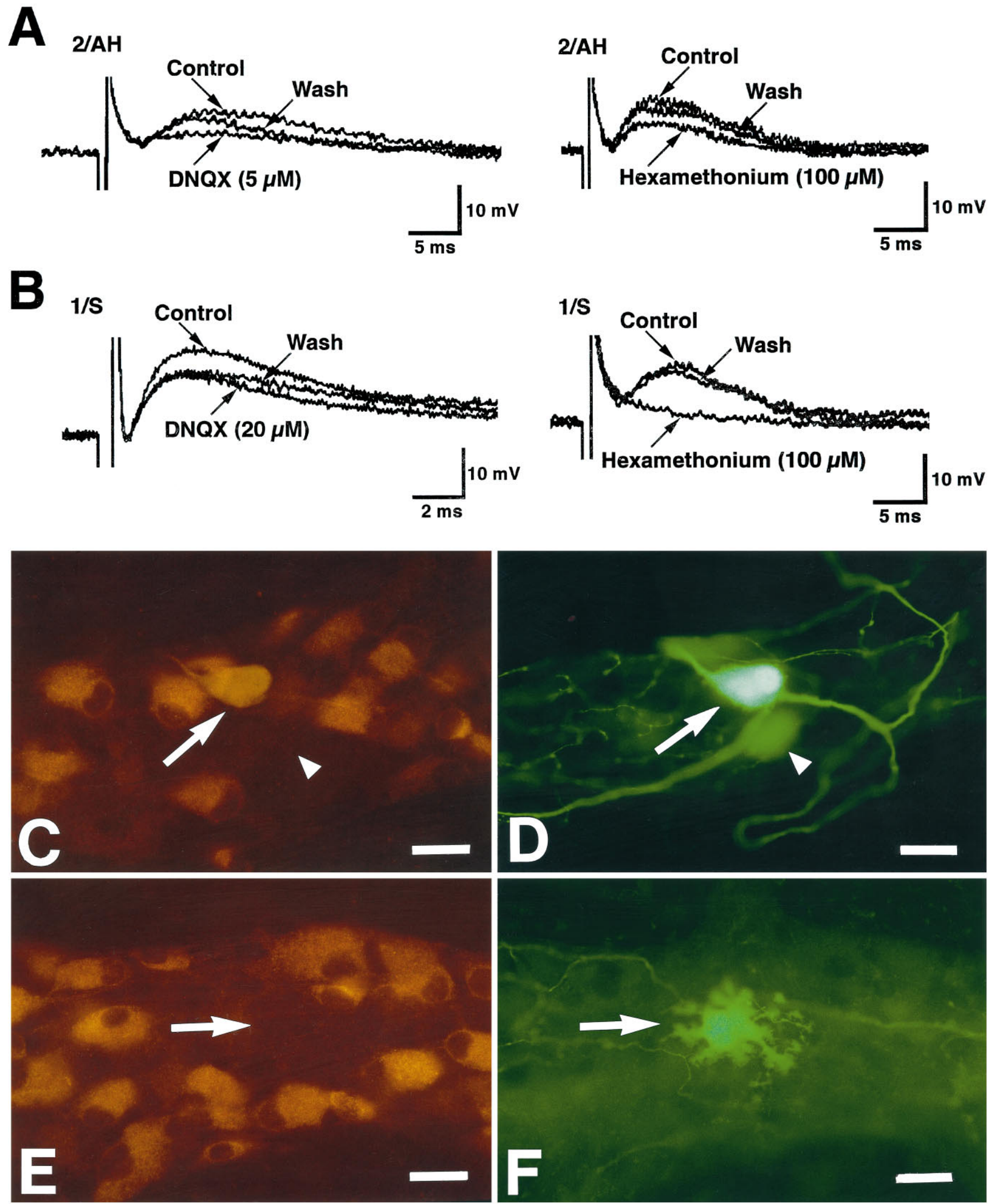

a $1 / \mathrm{S}$ cell is completely blocked by hexamethonium. Note that the recordings are obtained from different cells. Wash indicates recovery from DNQX or hexamethonium. $C-F$, Glutamate-responsive enteric neurons express GluR1 immunoreactivity. Fast responses to glutamate were recorded; neurons that did or did not respond to glutamate are marked by intracellular injection of Neurobiotin. A glutamate-responsive 2/AH neuron (arrow; this neuron also displayed a glutamatergic fast EPSP) is marked by both Neurobiotin (FITC; $D$ ) and GluR1 immunoreactivity (Cy3; $C$ ). In contrast, a Neurobiotin-injected 2/AH cell that did not respond to glutamate does not contain GluR1-immunoreactivity $(D$, arrowhead). $E, F$, A Neurobiotin-injected $1 / \mathrm{S}$ neuron (FITC; $F$ ) that did not respond to glutamate does not express GluR1 immunoreactivity (E, arrow). Scale bar, $30 \mu \mathrm{m}$. 

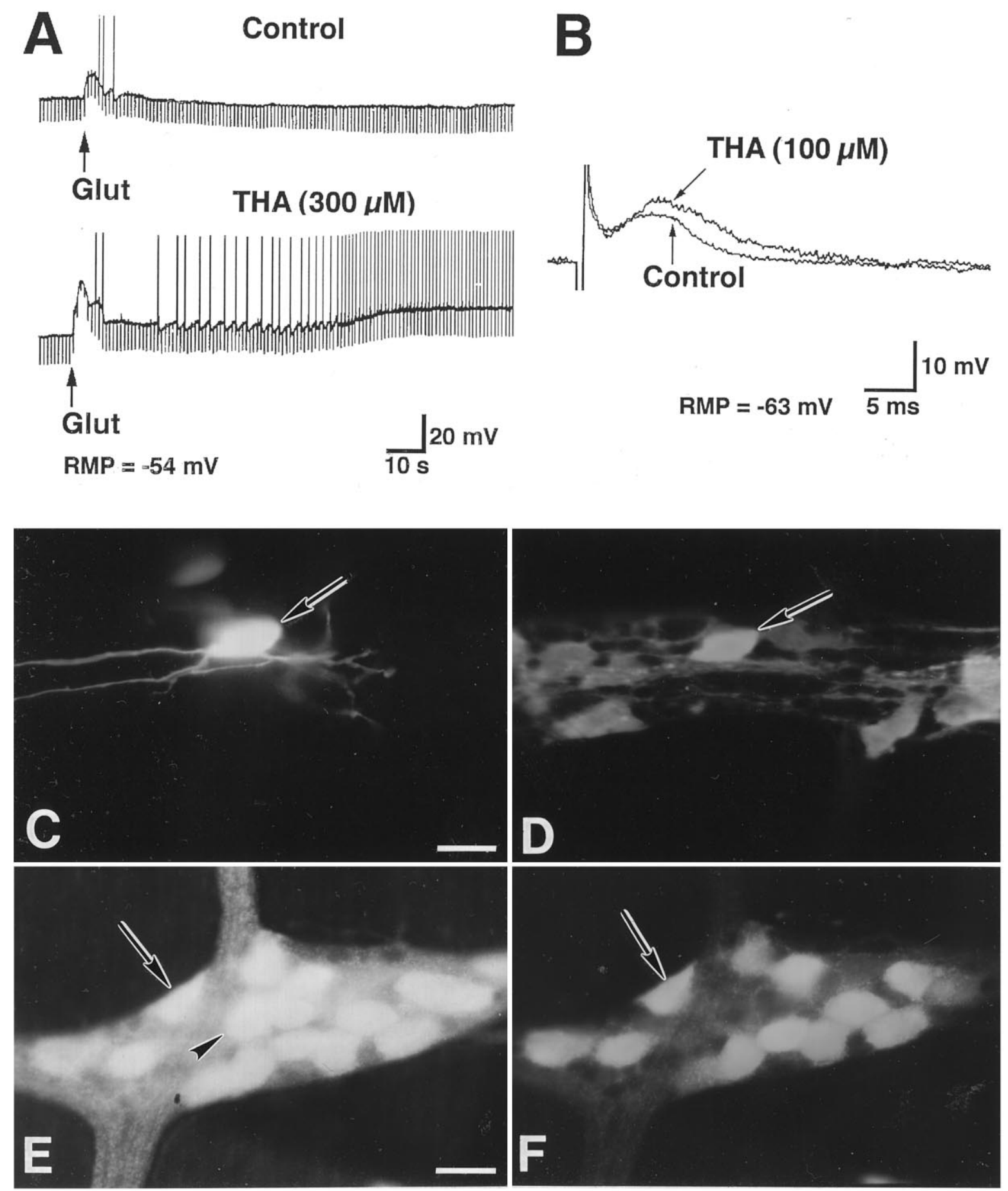

Figure 13. $A, B$, Inhibition of glutamate uptake potentiates both glutamate-mediated depolarizations and fast EPSPs in 2/AH neurons. Superfusion with THA, a specific high-affinity glutamate transport inhibitor, potentiates and prolongs the fast response to glutamate $(A)$ and the fast EPSP recorded in a $2 / \mathrm{AH}$ neuron $(B)$. $C, D$, Glutamate-responsive enteric neurons express the neuronal glutamate transporter EAAC1. A glutamate-responsive 2/AH neuron was marked by intracellular injection of Neurobiotin $(C$, arrow). The glutamate-responsive 2/AH neuron $(C)$ is EAAC1-immunoreactive $(D$, arrow). Neurobiotin was visualized with avidin-FITC. EAAC1 immunoreactivity was visualized with Cy3. E, $F$, EAAC1 immunoreactivity $(E$, arrow) is expressed by all calbindin-immunoreactive neurons $(F$, arrow) in the myenteric plexus; however, more neurons express EAAC1 immunoreactivity (arrowhead) than calbindin. Scale bar, $30 \mu \mathrm{m}$.

rons co-stored substance $\mathrm{P}$ and ChAT immunoreactivities, and a small subset was also calbindin-immunoreactive. The submucosal substance $\mathrm{P}$ - and ChAT-immunoreactive and substance P-, ChAT-, and calbindin-immunoreactive neurons are thought to be primary afferent neurons that project to the myenteric plexus
(Kirchgessner et al., 1992; Bornstein, 1994). The one-to-one relationship between glutamate and substance $\mathrm{P}$ immunoreactivities thus implies that the glutamate-immunoractive submucosal neurons are intrinsic sensory cells. The coincident localization of $\mathrm{ChAT}$ in all myenteric glutamate-immunoreactive neurons sug- 


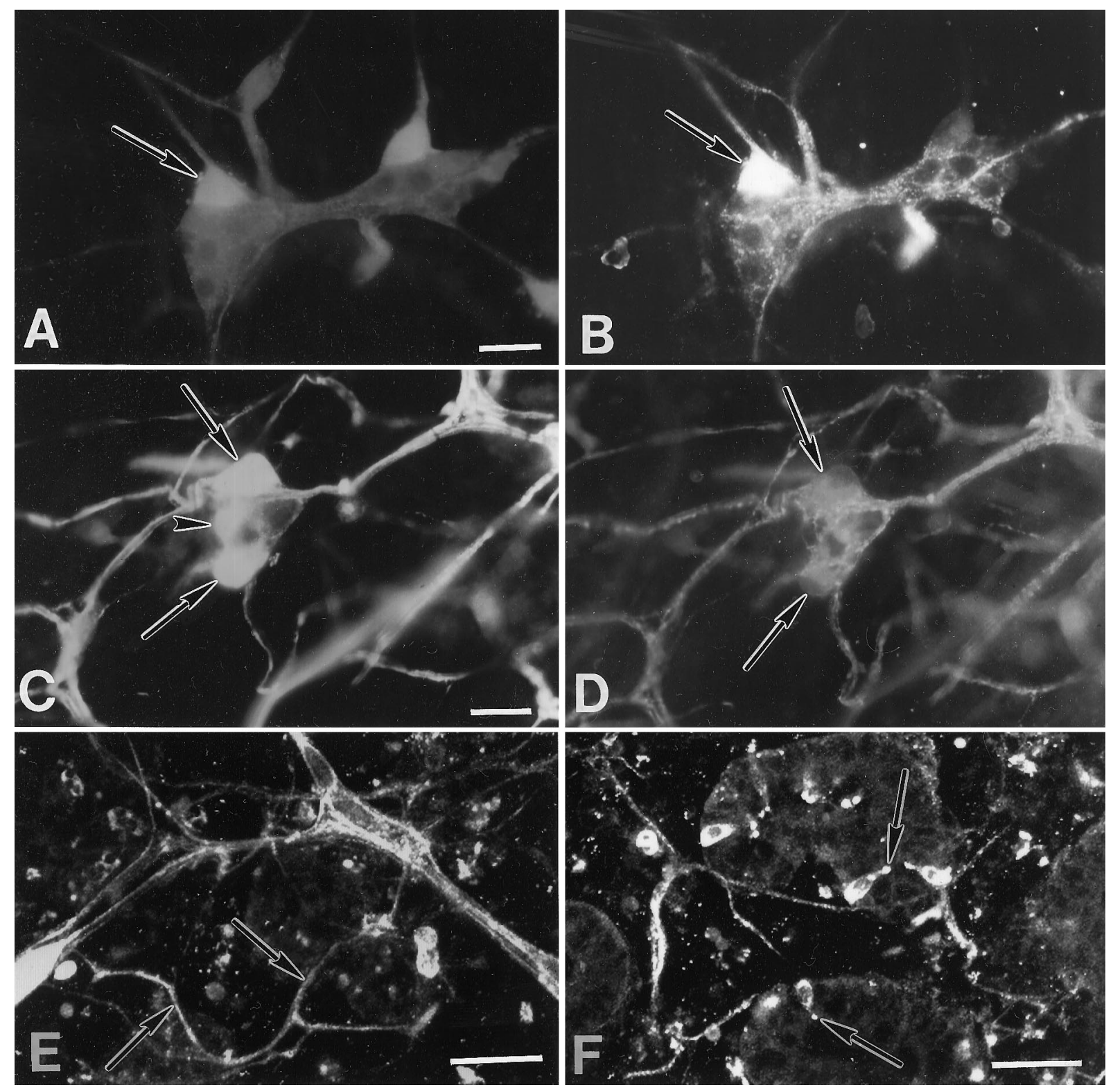

Figure 14. EAAC1-immunoreactive neurons are found in the submucosal plexus. $A, B$, A subset of EAAC1-immunoreactive neurons $(A)$ expresses calbindin immunoreactivity $(B$, arrow $) . C, D$, EAAC1 immunoreactivity $(C)$ is expressed by all substance P-immunoreactive neurons $(D$, arrow); however, not all EAAC1-immunoreactive neurons express substance $\mathrm{P}$ immunoreactivity (arrowhead). E, F, Confocal photomicrographs (sum of 10 optical sections, collected at $0.5 \mu \mathrm{m}$ intervals) of a whole mount of the submucosal plexus. EAAC1-immunoreactive nerve fibers encircle intestinal crypts $(E$, arrow). EAAC1 immunoreactivity is found in a subset of enterochromaffin cells $(F)$. The arrows indicate prominent staining of the apex of the cells facing the intestinal lumen. Scale bar, $30 \mu \mathrm{m}$.

gests that these neurons are likely to be excitatory because ACh is an excitatory neurotransmitter. The presence of an abundance of small, clear synaptic vesicles in glutamate-immunonoreactive varicosities is typical of peripheral cholinergic terminals (Jahn and Sudhof, 1994) and amino acid-containing terminals of the CNS (Storm-Mathisen et al., 1995). Because subsets of small, clear vesicles could not be distinguished, and glutamate immunoreactivity was associated with small, clear vesicles, it is possible that a single population of synaptic vesicles co-stores glutamate and ACh. The smaller population of large, dense-cored vesicles in the same terminals, which is typical of vesicles that contain a peptide (Thureson-Klein and Klein, 1990; Jahn and Sudhof, 1994), may in enteric glutamatergic terminals contain substance P.
The presence on specific subsets of enteric neurons of the immunoreactivities of glutamate receptor subunits correlates well with the responses of enteric neurons to glutamate as well as to its agonists and antagonists. The immunoreactivities of the AMPA receptor subunits were abundantly expressed, and virtually all enteric neurons were NMDA receptorimmunoreactive. In particular, the GluR1 subunit was found on most of the myenteric neurons that displayed 2/AH neuronal markers, such as calbindin immunoreactivity and Dogiel type 2 morphology. Correspondingly, glutamate evoked a complex response with one to three components in 2/AH neurons, and the fast component of this response was found to be mediated by AMPA receptors; thus, the fast response was mimicked by 
AMPA, blocked by the antagonists CNQX and DNQX, and potentiated by cyclothiazide, which interferes with the desensitization of AMPA receptors. The decrease in input resistance that accompanies the fast response to glutamate or AMPA and the rapidity of the response are consistent with the idea that the fast response is mediated by an ionotropic receptor. The presence of other subunits of AMPA receptors on different subsets of enteric neurons suggests that AMPA receptor-mediated glutamate responsivity is not limited to $2 / \mathrm{AH}$ neurons, a suggestion that was confirmed by the observation that $1 / \mathrm{S}$ neurons also exhibited fast responses to glutamate. The second, slower component of the response to glutamate was found to be mediated by NMDA receptors; thus, this component was mimicked by NMDA and inhibited by NMDA antagonists.

Fast EPSPs and slow EPSPs have been well characterized in enteric neurons (Wood, 1994). Fast EPSPs were originally described in $1 / \mathrm{S}$ neurons and were thought to be cholinergic and nicotinic (Hirst et al., 1974). More recently, however, it has become apparent that fast EPSPs are also exhibited by $2 / \mathrm{AH}$ neurons (Grafe et al., 1979; Schutte et al., 1995) and that ACh is not the only mediator of fast EPSPs (Galligan and Bertrand, 1994). In the current study, fast EPSPs in 2/AH neurons were found not to be abolished by hexamethonium, suggesting that ACh is not the sole mediator of fast EPSPs in these cells. The AMPA receptor-mediated fast component of the response to glutamate, moreover, mimicked fast EPSPs in 2/AH neurons; furthermore, the AMPA receptor antagonist DNQX inhibited fast EPSPs even more than did hexamethonium. These data are consistent with the idea that fast EPSPs in 2/AH neurons are mediated both by ACh and by glutamate. The coincident expression of glutamate and ChAT immunoreactivities in the same neurons suggests that $\mathrm{ACh}$ and glutamate are excitatory co-transmitters.

Because enteric neurons respond to glutamate, it is not clear why this effect was not observed previously. It is possible that earlier investigators applied glutamate in concentrations that were too low. We observed responses to glutamate only when its concentration in ejection pipettes was $\geq 20 \mathrm{~mm}$, which is higher than that usually used to test the effects of agonists on myenteric neurons. Responses of myenteric neurons to exogenous glutamate were found to be potentiated by glutamate uptake inhibitors (THA and PDC); furthermore, the immunoreactivity of the EEAC1 glutamate transporter (Rothstein et al., 1994) was widely expressed on the cell bodies of enteric neurons and in the ganglionic neuropil. These observations imply that the activity of the glutamate transporter attenuates responses to glutamate and suggest that the requirement for a high concentration of glutamate may be to enable the effects of the glutamate transporter to be overcome. The high concentration of glutamate may also compensate for glutamate receptor desensitization. Desensitization of the AMPA component of glutamate response can be minimized by adding cyclothiazide, which was not previously used in enteric studies of glutamate. Desensitization is also a problem that must be surmounted to investigate responses to glutamate in intact CNS tissue (Massey and Maguire, 1995). It is thus possible that the effects of glutamate on enteric neurons were not detected in earlier studies, because its effects were masked by uptake and/or desensitization.

The second, slower component of the response to glutamate may have been missed in previous studies, because recordings were made under conditions that are not optimal for the response. This slower-onset depolarization is probably mediated by NMDA receptors, because it is mimicked by NMDA and unaffected by the AMPA antagonists DNQX and CNQX. The NMDA receptormediated responses to glutamate were recorded in the presence of glycine and low concentrations of $\mathrm{Mg}^{2+}$. At high concentrations, glutamate stimulates the release of glycine (Ascher and Johnson, 1994). Glycine is a co-agonist that potentiaties NMDA responses and enables the activation of NMDA receptors by glutamate to become apparent (Johnson and Ascher, 1987). A high concentration of glutamate in the microejection pipette may release glycine from endogenous sources and thus may make evident the NMDA receptor-mediated component of the glutamate response. Low $\mathrm{Mg}^{2+}$ antagonizes a voltage-dependent block of the NMDA receptor and thus enhances NMDA receptor-mediated responses. In situ, the voltage-dependent block is overcome by the depolarization of potentially responsive neurons (Johnson and Ascher, 1990). The absence of constitutive depolarizing activity in myenteric neurons studied in vitro probably explains the requirement for low $\mathrm{Mg}^{2+}$.

The present findings strongly support the hypotheses that there are glutamatergic neurons in the ENS and that glutamate is an enteric neurotransmitter. To show that a compound is a neurotranmitter, that compound should be present in, and released from, presynaptic neurons; it should mimic the effects of the endogenous neurotransmitter; antagonizing the effects of the compound should interfere with synaptic transmission; and a suitable inactivating mechanism should be available to terminate responses to the compound. All of these criteria have been satisfied by glutamate. We have detected the immunoreactivities of glutamate, a glutamate transporter, and glutamate receptors (NMDA and AMPA) in subsets of enteric neurons in both plexuses. Glutamate, moreover, is selectively concentrated in terminal axonal varicosities. Fast EPSPs in 2/AH neurons are mimicked by AMPA and by the fast component of the glutamate response; moreover, fast EPSPs are inhibited by AMPA receptor antagonists. The extensive expression of the immunoreactivity of the EAAC1 glutamate transporter and the potentiation of both the fast component of the glutamate response and fast EPSPs by the glutamate uptake inhibitors THA and PDC indicate that transmembrane transport is the glutamate-inactivating mechanism. The release of glutamate from stimulated enteric nerves has been demonstrated previously (Wiley et al., 1991). The case for glutamate as an enteric neurotransmitter is thus compelling. Because excitotoxins active at glutamate receptors are present in food (Perl et al., 1990; Olney, 1994), the abundance of subsets of glutamate receptors in enteric neurons may render these cells vulnerable to glutamate-mediated excitotoxicity. The existence of enteric neurons and receptors that can play a role in processes such as activity-dependent plasticity and motor and associative memory supports the idea that the ENS is capable of a complex level of integrative function.

\section{REFERENCES}

Ascher P, Johnson JW (1994) The NMDA receptor, its channel, and its modulation by glycine. In: The NMDA receptor. (Collingridge GL, Watkins JC, eds), pp 177-205. Oxford: Oxford UP.

Balcar V, Johnston GAR, Twitchin B (1977) Stereospecificity of the inhibition of L-glutamate and L-aspartate high affinity uptake in the rat brain by threo-3-hydroxyaspartate. J Neurochem 28:1145-1146.

Bertrand PP, Galligan JJ (1995) Signal-transduction pathways causing slow synaptic excitation in guinea pig myenteric $\mathrm{AH}$ neurons. Am $\mathbf{J}$ Physiol 269:G710-G720. 
Bornstein J (1994) Local neural control of intestinal motility: nerve circuits deduced for the guinea-pig small intestine. Clin Exp Pharmacol Physiol 21:441-452.

Bornstein JC, Hendriks R, Furness JB, Trussell DC (1991) Ramifications of the axons of AH-neurons injected with the intracellular marker biocytin in the myenteric plexus of the guinea pig small intestine. J Comp Neurol 314:437-451.

Burns GA, Stephens KE (1995) Expression of mRNA for the $N$-methylD-aspartate (NMDAR1) receptor and vasoactive intestinal polypeptide (VIP) co-exist in enteric neurons of the rat. J Auton Nerv Syst 55:207-210.

Burns GA, Stephens KE, Benson JA (1994) Expression of mRNA for the $N$-methyl-D-apartate (NMDAR1) receptor by the enteric neruons of the rat. Neurosci Lett 170:87-90.

Costa M, Brookes SJH, Steele PA, Gibbins I, Burcher E, Kandiah CJ (1996) Neurochemical classification of myenteric neurons in the guinea-pig ileum. Neuroscience 75:949-967.

Erde SM, Sherman D, Gershon MD (1985) Morphology and serotonergic innervation of physiologically identified cells of the guinea pig's myenteric plexus. J Neurosci 5:617-633.

Furness JB, Costa M (1987) The enteric nervous system. New York: Churchill Livingstone.

Furness JB, Costa M, Keast JR (1984) Choline acetyltransferase and peptide immunoreactivity of submucous neurons in the small intestine of the guinea-pig. Cell Tissue Res 237:329-336.

Furness JB, Bornstein JC, Pompolo S, Young HM, Kunze WAA, Kelly H (1994) The circuitry of the enteric nervous system. Neurogastroenterol Mot 6:241-253.

Galligan JJ, Bertrand PP (1994) ATP mediates fast synaptic potentials in enteric neurons. J Neurosci 14:7563-7571.

Galligan JJ, North RA (1990) MK-801 blocks nicotinic depolarization of guinea pig myenteric neurons. Neurosci Lett 108:105-109.

Gasic G (1995) Systems and molecular genetic approaches converge to tackle learning and memory. Neuron 15:507-512.

Gershon MD, Kirchgessner AL, Wade PR (1994) Functional anatomy of the enteric nervous system. In: Physiology of the gastrointestinal tract, Ed 3 (Johnson LR, Alpers DH, Jacobson ED, Walsh JH, eds), pp 381-422. New York: Raven.

Grafe P, Mayer CJ, Wood JD (1979) Fast excitatory postsynaptic potentials in $\mathrm{AH}$ (type 2) neurons of guinea-pig myenteric plexus. Brain Res 163:349-352.

Harris EW (1995) Subtypes of glutamate receptors: pharmacological classification. In: CNS neurotransmitters and neuromodulators: glutamate (Stone TW, ed), pp 95-125. New York: CRC.

Hirst GDS, Holman ME, Spence I (1974) Two types of neurons in the myenteric plexus of duodenum in the guinea-pig. J Physiol (Lond) 236:303-326.

Hollmann M (1997) The topology of glutamate receptors: sorting through the domains. In: The ionotropic glutamate receptors (Monaghan DT, Wenthold RJ, eds), pp. 39-80. Totowa, NJ: Humana.

Hollmann M, Hartley M, Heinemann S (1991) $\mathrm{Ca}^{2+}$ permeability of KA-AMPA-gated glutamate receptor channels depends on subunit composition. Science 252:851-854.

Iyer V, Bornstein JC, Costa M, Furness JB, Takahashi Y, Iwanaga T (1988) Electrophysiology of guinea-pig myenteric neurons correlated with immunoreactivity for calcium binding proteins. J Auton Nerv Syst 22:141-150.

Jacobowitz DM, Winsky L (1991) Immunocytochemical localization of calretinin in the forebrain of the rat. J Comp Neurol 304:198-218.

Jahn R, Sudhof TC (1994) Synaptic vesicles and exocytosis. Annu Rev Neurosci 17:219-246.

Johnson JW, Ascher P (1987) Glycine potentiates the NMDA receptor response in cultured mouse brain neurones. Nature 325:529-531.

Johnson JW, Ascher P (1990) Voltage-dependent block by intracellular $\mathrm{Mg}^{2+}$ of $N$-methyl-D-aspartate-activated channels. Biophys $\mathrm{J} 57$ 1085-1090.

Kanai Y, Bhide PG, DiFiglia M, Hediger MA (1995) Neuronal high affinity glutamate transport in the rat central nervous system. NeuroReport 6:2357-2362.

Kirchgessner AL, Gershon MD (1988) Projections of submucosal neurons to the myenteric plexus of the guinea pig intestine: in vitro tracing of microcircuits by retrograde and anterograde transport. J Comp Neurol 277:487-498.

Kirchgessner AL, Tamir H, Gershon MD (1992) Identification and stimulation by serotonin of intrinsic sensory neurons of the submucosal plexus of the guinea pig gut: activity-induced expression of Fos immunoreactivity. J Neurosci 12:235-249.

Mannaioni G, Alesiani M, Carla V, Natalini B, Marinozzi M, Pellicciari R, Moroni F (1994) Sulfate esters of hydroxy amino acids as stereospecific glutamate receptor agonists. Eur J Pharmacol 251:201-207.

Marc RE, Liu W-L, Kalloniatis M, Raiguel SF, Haesendock E (1990) Patterns of glutamate immunoreactivity in the goldfish retina. J Neurosci 10:4006-4034.

Massey SC, Maguire G (1995) The role of glutamate in retinal circuitry. In: Excitatory amino acids and synaptic transmission (Wheal H, Thomson A, eds), pp 201-221. New York: Academic.

Mayer CJ, Camerer H, Dembowsky K, Grafe P, Steiger A (1982) Actions of amino acid neurotransmitters on myenteric neurons. In: Motility of the digestive tract (Wienbeck M, ed), pp 103-108. New York: Raven.

McConalogue K, Furness JB, Vremec MA, Holst JJ, Tornoe K, Marley PD (1995) Histochemical, pharmacological, biochemical and chromatographic evidence that pituitary adenylyl cyclase activating peptide is involved in inhibitory neurotransmission in the taenia of the guineapig caecum. J Auton Nerv Syst 50:311-322.

McGehee DS, Heath MJS, Gelber S, Devay P, Role LW (1995) Nicotine enhancement of fast excitatory synaptic transmission in CNS by presynaptic receptors. Science 269:1692-1696.

Monaghan DT, Bridges RJ, Cotman CW (1989) The excitatory amino acid receptors: their classes, pharmacology, and distinct properties in the function ofthe central nervous system. Annu Rev Pharmacol Toxicol 29:365-402.

Neunlist M, Schemann M (1997) Projections and neurochemical coding of myenteric neurons innervating the mucosa of the guinea pig proximal colon. Cell Tissue Res 287:119-125.

Olney JW (1994) Excitotoxins in foods. Neurotoxicology 15:535-544.

Pan H, Wang H-Y, Friedman E, Gershon MD (1997) Mediation by protein kinases $\mathrm{C}$ and $\mathrm{A}$ of Go-linked slow responses of enteric neurons to 5-HT. J Neurosci 17:1011-1024.

Perl TM, Bedard L, Kosatsky T, Hockin JC, Todd ECD, Remis RSN (1990) An outbreak of toxic encephalopathy caused by eating mussels contaminated with domoic acid. N Engl J Med 322:1775-1780.

Petralia RS, Wenthold RJ (1992) Light and electron immunocytochemical localization of AMPA-selective glutamate receptors in the rat brain. J Comp Neurol 318:329-354.

Petralia RS, Yokotani N, Wenthold RJ (1994a) Light and electron microscopic distribution of the NMDA receptor subunit NMDAR1 in the rat nervous system using a selective anti-peptide antibody. J Neurosci 14:667-696.

Petralia RS, Wang Y-X, Wenthold RJ (1994b) The NMDA receptor subunits NR2A and NR2B show histological and ultrastructural localization patterns similar to those of NR1. J Neurosci 14:6102-6120.

Rhoads JM, Argenzio RA, Chen W, Gomez GG (1995) Asparagine stimulates piglet intestinal $\mathrm{Cl}$ secretion by a mechanism requiring a submucosal glutamate receptor and nitric oxide. J Pharmacol Exp Ther 274:404-412.

Rothstein JD, Martin L, Levey AI, Dykes-Hoberg M, Jin L, Wu D, Nash N, Kuncl RW (1994) Localization of neuronal and glial glutamate transporters. Neuron 13:713-725.

Schutte IWM, Kroese ABA, Akkermans LMA (1995) Somal size and location within the ganglia for electrophysiologically identified myenteric neurons of the guinea pig ileum. J Comp Neurol 355:563-572.

Shannon HE, Sawyer BD (1989) Glutamate receptors of the $N$-methylD-aspartate subtype in the myenteric plexus of the guinea pig ileum. J Pharmacol Exp Ther 251:518-523.

Song Z-M, Brookes SJH, Costa M (1991) Identification of myenteric neurons which project to the mucosa of the guinea-pig small intestine. Neurosci Lett 129:294-298.

Storm-Mathisen J, Danbolt NC, Ottersen OP (1995) Localization of glutamate and its membrane transport proteins. In: CNS neurotransmitters and neuromodulators: glutamate (Stone TW, ed), pp 1-18. New York: CRC.

Takaki M, Branchek T, Tamir H, Gershon MD (1985) Specific antagonism of enteric neural serotonin receptors by dipeptides of 5-hydroxytryptophan: evidence that serotonin is a mediatory of slow synaptic excitation in the myenteric plexus. J Neurosci 5:1769-1780.

Thureson-Klein AK, Klein RL (1990) Exocytosis from neuronal large dense cored vesicles. Int Rev Cytol 121:67-126.

Tong G, Jahr CE (1994) Block of glutamate transporters potentiates postynaptic excitation. Neuron 13:1195-1203. 
van den Pol AN (1991) Glutamate and aspartate immunoreactivity in hypothalamic presynaptic axons. J Neurosci 11:2087-2101.

van den Pol AN, Wuarin J-P, Dudek FE (1990) Glutamate, the dominant excitatory transmitter in neuroendocrine regulation. Science 250:1276-1278.

Vodyanoy V (1995) Glutamate-activated ion channels. In: CNS neurotransmitters and neuromodulators: glutamate (Stone TW, ed), pp 127142. New York: CRC.

Wade PR, Tamir H, Kirchgessner AL, Gershon MD (1994) Analysis of the role of 5 -HT in the enteric nervous system using anti-idiotypic antibodies to 5-HT receptors. Am J Physiol 266:G403-G416.

Weaver CD, Yao TL, Powers AC, Verdoorn TA (1996) Differential expression of glutamate receptor subtypes in rat pancreatic islets. $\mathrm{J}$ BiolChem 271:12977-12984.

Wenthold RJ, Altschuler RA, Hampson DR (1990) Immunocytochemistry of neurotransmitter receptors. J Electron Microsc Tech 15:81-96.
Wenthold RJ, Yokotani N, Doi K, Wada K (1992) Immunohistochemical characterization of the non-NMDA glutamate receptor using subunitspecific antibodies. Evidence for a hetero-oligomeric structure in rat brain. J Biol Chem 267:501-507.

Wiley JW, Lu Y, Owyang C (1991) Evidence for a glutamatergic neural pathway in the myenteric plexus. Am J Physiol 261:G693-G700.

Wong HC, Sternini C, Lloyd K, DeGiorgio R, Walsh JH (1996) Monoclonal antibody to VIP: production, characterization, immunoneutralizing activity, and usefulness in cytochemical staining. Hybridoma 15:133-139.

Wood JD (1994) Physiology of the enteric nervous system. In: Physiology of the gastrointestinal tract, Ed 3 (Johnson LR, Alpers DH, Jacobson ED, Walsh JH, eds), pp. 423-482. New York: Raven.

Wood JD, Mayer CJ (1979) Serotonergic activation of tonic-type enteric neurons in guinea pig small bowel. J Neurophysiol 422:582-593. 